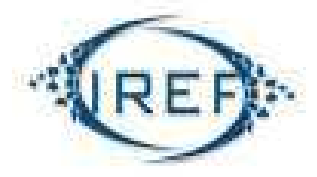

WORKING PAPER SERIES

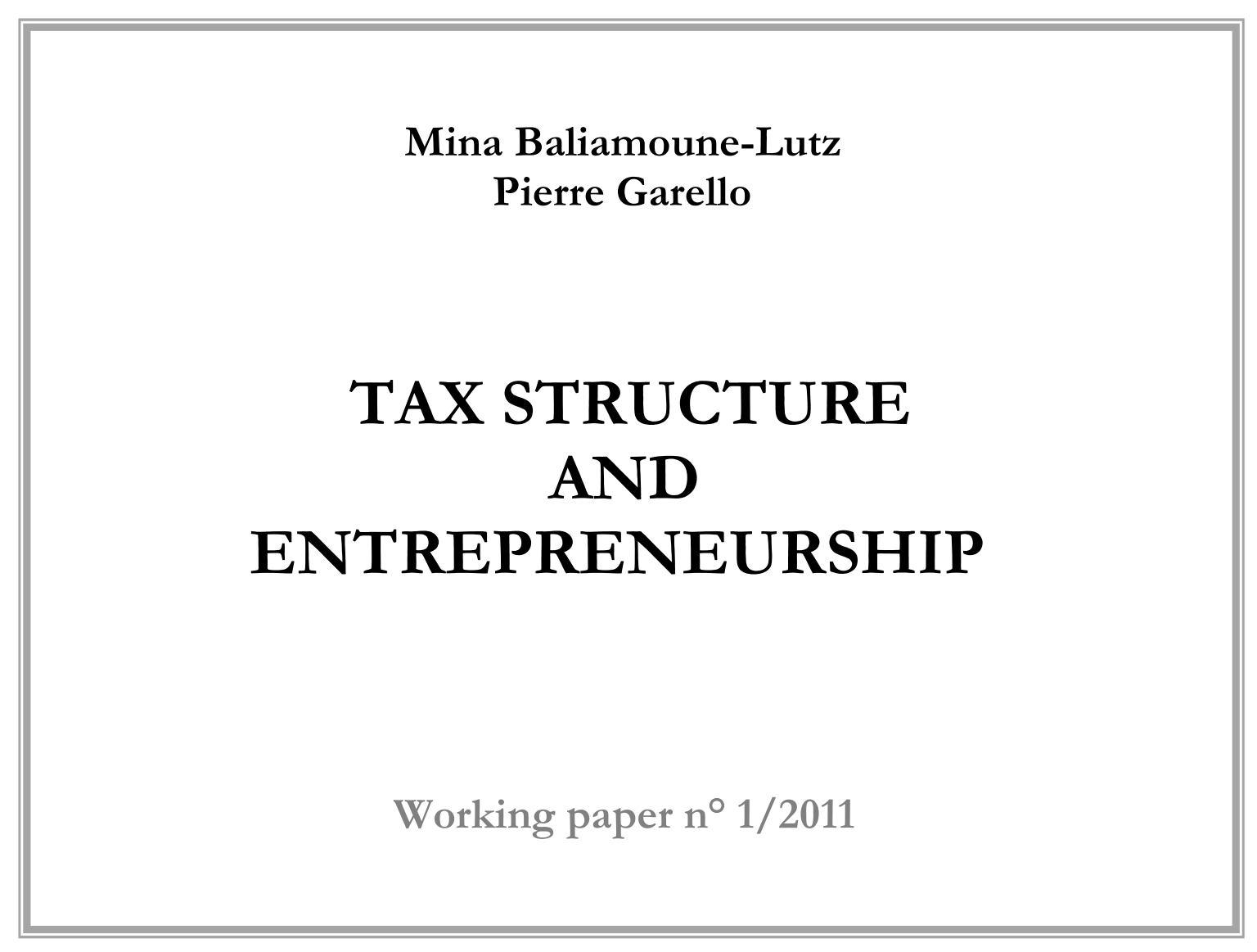




\title{
Tax structure and entrepreneurship
}

\author{
Mina Baliamoune-Lutz, ${ }^{*}$ University of North Florida \\ and
}

Pierre Garello, Aix-Marseille University

\begin{abstract}
Using macro-level panel data, we examine the effects of taxation and tax progressivity on entrepreneurship in a large group of European countries. We address two main objectives. First, we try to explore whether tax increases discourage entrepreneurial activity, focusing on new self-employment (nascent entrepreneurship). Second, we investigate the impact of tax progressivity on entrepreneurship, again focusing on the impact on new self-employment. We find that tax progressivity at higher-than-average incomes has a robust negative effect on nascent entrepreneurship. We discuss the policy implications of our results.
\end{abstract}

* Corresponding author. Department of Economics, University of North Florida, Jacksonville, email: mbaliamo@unf.edu.

The authors gratefully acknowledge research fellowships provided by the Institute for Research on Economic and Fiscal Issues (IREF) and very helpful comments and suggestions made by Enrico Colombatto, Sergio Beraldo, and participants in the Research Workshop held at Aix-Marseille University, September 12, 2011. The usual disclaimer applies. 
The theory of externalities implies taxes should be highest where activity has negative social costs (e.g. pollution) and lowest where the activity has positive social benefits (e.g. innovation). In practice, the tax code is a thicket of anti-entrepreneurial incentives and a source of red tape compliance burden. Taxes influence ownership structure, job creation, financing structure, and often the very decision to start a business.

Source: http://www.entrepreneurship.org/en/policy-forum

\section{Introduction}

Numerous, and often conflicting, principles guide the design of a tax structure. One of those principles is that taxation should promote growth, or at least should hamper it as little as possible. Because innovation has been shown to be an important engine of long-term growth and development, and because innovation often takes place in settings where entrepreneurship is vibrant, a successful implementation of that principle requires that the impact of the tax structure on entrepreneurship be taken into account. ${ }^{1}$

The present study focuses on European countries. Strangled by a sovereign debt crisis that followed a deep financial crisis, governments in those countries are in desperate need for tax revenues. ${ }^{2}$ If in the past some OECD governments have emphasized the link between tax cuts and entrepreneurship as the basis of their tax cut policies (for e.g., during the Reagan and Thatcher administrations in the 1980s), most large European Union countries have today bad rankings in terms of tax rates and tax regulations. According to the 2010-2011 Global Competitiveness Report by the World Economic Forum (WEF), tax regulations and tax rates were among the top four factors that are most problematic for doing business in many E.U. countries. For example, tax regulations were the most problematic factor for doing business in

\footnotetext{
${ }^{1}$ Interestingly, it has been shown that institutional and policy reforms (including tax reforms) can influence the growth effects of entrepreneurship in a non-linear way. Hence, policy reforms, such as trade liberalization, have a stronger positive impact on growth when entrepreneurship is strong while some institutional reforms work best on growth where entrepreneurship is weak and can be detrimental to the effect of entrepreneurship on growth where entrepreneurial activity is high (see, for example, Baliamoune-Lutz, 2007 and 2010).

${ }^{2}$ Whether monetary policy offers an alternative way to budgetary and fiscal policy is an open question. As a matter of fact, besides fiscal reforms, governments have been injecting money for the past four years and are now turning towards Eurobonds (which is quasi-monetary). Which one of a monetary or a budgetary policy is more efficient and how the two policies interact is not the topic of this paper, however. See Alesina and Ardagna (2009) for a recent empirical treatment of the question.
} 
Germany and tax rates were the most problematic factor for doing business in the U.K. ${ }^{3}$ As further evidence of a tax structure that seems to be paying little attention to business, in the 2010 edition of its Taxation in Europe Yearbook (henceforth IREF 2010), l'Institut de recherches économiques et fiscales (IREF) reports that while there are recent tax reforms or changes that have been enacted with the view to promote entrepreneurship (e.g., in the Netherlands, Austria and Bulgaria), many of the countries included in the 2010 yearbook still have tax structures that do not seem particularly favorable to entrepreneurs and selfemployment.

The task of designing the appropriate tax structure is nowadays quite difficult, and the fact that economies are more globalized makes it even more complex. ${ }^{4}$ Because economic and financial crises can cause significant increases in unemployment, governments may be tempted to alter the tax structure by introducing new taxes or increasing marginal tax rates, instead of cutting government spending. But this new or higher tax burden could in turn constitute an impediment to entrepreneurship, growth, employment and tax revenues. To progress in that discussion on the appropriate tax structure, more empirical work on the impact of higher taxes on entrepreneurial activity is warranted. Such work may provide useful insight that could help explain why this type of fiscal policy (increasing taxes as opposed to cutting government spending) may have a negative impact on growth.

In this paper, we examine how the tax structure affects entrepreneurship in a large group of European countries. To do this, we use country data on nascent entrepreneurship from the Global Entrepreneurship Monitor (GEM) and relevant tax rates from the Organization for Economic Co-operation and Development (OECD) Tax Database. More specifically, using panel data for 2000-2008, the paper addresses two main objectives. First, controlling for other relevant variables, we try to explore whether tax increases discourage entrepreneurial activity, focusing on the effects on new self-employment (nascent entrepreneurship). Second, we

\footnotetext{
${ }^{3}$ Amongst 139 countries covered by the report, the U.K., Germany, France, and Italy ranked $54^{\text {th }}, 84^{\text {th }}, 125^{\text {th }}$, and $126^{\text {th }}$, respectively, in the component on total tax rates and $95^{\text {th }}, 90^{\text {th }}, 108^{\text {th }}$, and $133^{\text {rd }}$, respectively, in the component on the extent and effect of taxation.

${ }^{4}$ Globalization implies increased ability to take advantage of more favorable fiscal environments and the avenues offered by transfer pricing (see for e.g., Haufler and Schjeledrup, 2000) by locating the business or part of it outside the entrepreneur's home country.
} 
investigate the impact of tax progressivity on new self-employment. This study differs from existing empirical work using European data because it uses macro-level panel data (the literature contains mostly studies using micro-level data due mainly to the difficulty to incorporate the concept of tax progressivity at the macro-level) and makes the distinction between the effect of taxes and tax progressivity on new entrepreneurial activity (nascent entrepreneurship) using several measures of taxation.

The remainder of the paper proceeds as follows. In Section 2, we comment on the link between entrepreneurship and growth. In Section 3, we present a theoretical discussion and a survey of recent empirical literature on entrepreneurship and taxation. In Section 4, we describe the variables and methodology. Section 5 presents the estimation results. We summarize and provide a policy discussion in the final section.

\section{Entrepreneurship and growth in a nutshell}

It is widely held that the link between entrepreneurship and growth is a strong one (see Figure 1 using data from the sample in our empirical analysis) and, indeed, that entrepreneurship is essential to growth. ${ }^{5}$ As a matter of fact, growth theory has long acknowledged that capital and labor alone cannot explain growth: the mere accumulation of 'human capital' is not sufficient. What is required is the 'talent' of combining pieces of knowledge to create value, and this is precisely what entrepreneurship is about. If so, then the impact of taxation on growth would depend, at least partly, on the impact of taxation on entrepreneurship. As a consequence, if the impact of taxation on entrepreneurship is complex, so will be the relationship between taxation and growth. Hence, careful study of how taxation links to entrepreneurship could shed some light on the apparent contradiction prevailing in the contemporary empirical literature on taxation and growth. While one strand of the theoretical and empirical literature on the subject

\footnotetext{
5 But the link is not necessarily straightforward. For instance, the link between new business formation (admittedly an imperfect proxy for entrepreneurship, as will be discussed below) and growth is both direct and indirect (e.g., displacement of incumbent businesses and byproducts of innovation) and part of the start-ups contributes little to growth. See Fritsch (2011) for a recent survey.
} 
claims that fiscal policy has barely any impact on the rate of growth, ${ }^{6}$ others have claimed that fiscal policy does have a strong impact on growth.

Admitting, at least for the sake of discussion, that entrepreneurship is an essential ingredient to growth, it is natural to inquire into what promotes and what hinders it. To answer that question requires first that we clarify what entrepreneurship means. There exist many possible definitions of entrepreneurship. For the present investigation it is useful to start from a broad one. Kirzner, qualifies as entrepreneur any market participant whose actions are guided by the perception of a profit opportunity. Profit opportunities, in turn, emerge when allocation of efforts in the economy is sub-optimal given available (but dispersed) knowledge. In a global economy where complexity is ever increasing (due to further division of labor) and consequently where knowledge is more dispersed, taking advantage of better (smarter) ways of allocating resources is essential. This explains naturally why entrepreneurship - the perception and grabbing of profit opportunities - is a key ingredient to growth; the real engine of growth.

However, it is important for the present study to rely on a definition of entrepreneurship that is even broader than the Kirznerian one and acknowledges that individuals do not always exercise their 'entrepreneurial talents' on the market, if by market we mean voluntary exchange between private agents. Some might, for instance, be vigilant to opportunities of improving their well-being through fiscal strategy. Others might look for rent-seeking strategies. In those cases, entrepreneurship - in its broadest definition - does not exclusively describe the attitude of market participants hunting for profit opportunities; it includes the behavior of any economic agent using her creativity to increase her personal well-being. ${ }^{7}$

The concrete forms that entrepreneurship can take on the market are infinite: The middleman, combining knowledge of production possibilities with knowledge of consumers' needs is one of them. The innovator-entrepreneur that herself develops a new software program and markets it, the lawyer that opens a new office in town, the restaurant owner, etc. are manifestations of entrepreneurship.

\footnotetext{
${ }^{6}$ This could be referred to as the Harberger's conjecture. See Mendoza et al. (1997).

${ }^{7}$ An idea developed in Baumol (1990).
} 
Hence, if the goal is growth, one must look for the conditions leading individuals to direct their entrepreneurial talent towards the market, that is, towards wealth creation. ${ }^{8}$ So what drives entrepreneurship towards wealth creation? It is surely a combination of many parameters including imagination, creativity, self-confidence or education. But one obvious precondition for directing entrepreneurial talent towards the market is the presence of profit opportunities and probably 'the size' of those opportunities. This, in turn, requires that the market functions properly. The market being the process that develops when property rights can be freely exchanged, actions and instruments that improve the system of property rights (clearly defined, well defended and easily divestible) would promote economic activity in general and entrepreneurship in particular. Inversely, anything that weakens this system-such as regulatory invasion and, more generally, legal uncertainty, quotas, tariffs-would reduce entrepreneurial actions on the market. ${ }^{9}$ Another obvious candidate for a determinant of the level of entrepreneurial talent exercised on the market is the fiscal policy which impacts both on the size of profit opportunities and on the level of well-being that can be reached when entrepreneurial talent is directed away from wealth creation.

\section{Entrepreneurship and taxation}

\subsection{Theoretical discussion}

From the understanding of entrepreneurship quickly outlined above, it follows that the link between taxation, entrepreneurship and growth could be a simple one: since higher taxation reduces the level of profit opportunities (incentive effect), it is likely to reduce productive entrepreneurship and therefore growth.

The theoretical literature generally brings support to that understanding, with some caveat and dissent, however. In general, the literature shows a negative link between corporate tax rates

\footnotetext{
${ }^{8}$ The story about wealth creation is in fact a story about productive versus unproductive entrepreneurship. See Baumol (1990) and Colombatto and Melnik (2008).

${ }^{9}$ The present study focuses on European countries that have reached similar levels of development and where enforcement of the rule of law is roughly the same, so we will not test for the influence of a proper definition and protection of rights on entrepreneurship.
} 
and economic growth and between tax structure and entrepreneurship. For example, the theoretical model in Keuschnigg and Nielsen (2002) suggests that progressive taxation retards entrepreneurship and the expansion of innovative industries. Kitao (2008) uses an augmented standard Bewley model with an entrepreneurial sector and occupational heterogeneity to examine the major channels through which fiscal policies influence factor prices, aggregate variables, wealth distribution, and welfare. The author finds that reducing the tax burden on capital formation stimulates investment, but the effects depend on whether the target is entrepreneurial capital or non-entrepreneurial capital. Kitao presents evidence indicating that a flat business tax of $10 \%$ will raise entrepreneurial investment by $20 \%$ in the long run (although this should depend on the starting point) and lead to an increase in wages of $5 \%$. However, some studies have pointed out that the effect of higher taxes on entry into entrepreneurship could be positive (Domar and Musgrave, 1944) or ambiguous (Gentry and Hubbard, 2000, 2004a).

Key to explaining this theoretical ambiguity is the impact of risk and uncertainty on entrepreneurship. It is often believed that the entrepreneur is a risk lover or at least, that she is less averse to risk than the employee; but this is not necessarily the case. True, the flow of future incomes is apparently easier to predict in the case of an employee who has signed a contractual arrangement with an employer (although obviously the employing company might run into difficulties and the employee could lose her job). But one should remember that the entrepreneur is usually someone who is convinced that there is out there an opportunity to be grasped.

A low aversion to risk is therefore not necessarily something that characterizes the entrepreneur. Perhaps one could say that an attitude towards risk is what distinguishes the entrepreneur in the sense that, while the employee is relatively passive and chooses to rely entirely on the talent of the employer, the entrepreneur is trying to anticipate, to see further down the road. In other words, the path taken by the employee is not necessarily safer than the path taken by the entrepreneur. Nevertheless, because entrepreneurs are not necessarily risk lovers, they will usually appreciate a reduction in risk for a given expected return. In particular if they can take the profits and have someone else bear the eventual losses, this should make 
the entrepreneurial move more attractive. When it comes to taxation, at least two consequences follow. First, a progressive income tax scheme is equivalent for a self-employed to a bonus (or subsidy) when incomes turn out to be lower than expected. In other words, the self-employed will pay high taxes only if successful. Second, whenever losses are, partly or fully, deductible from future tax duties, the entrepreneur will be more inclined to be self-employed. Both of these outcomes imply the possibility of an 'insurance' effect, reflected in the positive impact of progressive taxes on entrepreneurship. As noted by Gentry and Hubbard (2000: 284), "When greater tax progressivity can offer insurance through the tax system against uninsured idiosyncratic risk, entry may be enhanced." Thus, theoretical models point to an ambiguous impact of tax progressivity on entrepreneurship (or self-employment). Indeed, existing theoretical models show that:

(i) If the entrepreneur is risk neutral then a proportional income tax with full loss offset $^{10}$ will have no impact on the decision to become self-employed or be a regular employee (Gentry and Hubbard, 2000).

(ii) For the same risk neutral entrepreneur, a "success" tax with imperfect loss offset will reduce, relatively to the situation described in (i), the number of selfemployed ${ }^{11}$ (Gentry and Hubbard, 2000).

(iii) If the entrepreneur is risk averse, then a progressive tax schedule might work as an insurance scheme and increase entry into self-employment relatively to a proportional tax scheme (Domar and Musgrave, 1944). ${ }^{12}$

\footnotetext{
${ }^{10}$ By full loss offset it is meant here that the entrepreneur can deduce from her future tax liability the loss times the tax rates. Hence for a tax rate of $t$ and loss of $L$ the amount $t \times L$ can be deduced from the future tax liability. So that it is as if the loss had been limited to $(1-t) L$.

${ }^{11}$ In this context, 'success tax' refers to a situation where the entrepreneur will de facto pay income taxes at a higher rate when successful at making profit than when unsuccessful.

${ }^{12}$ Another, maybe more intuitive, explanation could be the fact that higher progressivity means higher redistribution and better environment and therefore more entrepreneurship. We thank Sergio Beraldo for pointing out this channel.
} 


\subsection{Taxes and entrepreneurial activity: A survey of recent empirical literature}

The empirical literature on the effects of taxes on entrepreneurship is fairly large but tends to contain mixed evidence. Empirical studies have explored the implications of the level (rates) and structure of taxes, focusing in general on the impact on labor markets, job mobility, entrepreneurship and economic growth. However, the empirical evidence on these effects, both at the macro and micro levels, remains mixed. In the following non-exhaustive survey of recent studies, we will focus on two major areas: (i) the effects of tax increases (or tax cuts) on the creation and growth of entrepreneurship (or self-employment), and (ii) the impact of tax progressivity on entrepreneurship.

A number of empirical studies present evidence on the effects of taxes on self-employment and small firms in OECD countries (see Table 1 for a summary). ${ }^{13}$ For example, based on tax returns of sole proprietors before and after the US Tax Reform Act of 1986, Carroll et al. (2000) examine the impact of the entrepreneur's personal income-tax rates on hired labor. The authors report that a $10 \%$ increase in the entrepreneur's tax price-defined as one minus the marginal tax rate-increases the average probability of hiring by approximately $12 \%$. Using US data from tax returns between 1985 and 1988, Carroll et al. (2001) report that a reduction in the marginal tax rate from $50 \%$ to $33 \%$ would result in an increase in revenues of about $28 \%$. Schuetze (2000) examines the trends in male self-employment in Canada and the U.S. using micro data for the period 1983-1994 and focusing on the role of taxes and economic conditions. He finds that higher income tax and unemployment rates are positively correlated with an increase in the rates of self-employment among North American men, with changes in the tax environment accounting for a large portion of the secular trend in male selfemployment. Gentry and Hubbard (2000 and 2005) examine the effects of tax policy on selfemployment and conclude that the level of the marginal tax rate and the progressivity of the tax have a negative influence on entrepreneurship.

\footnotetext{
${ }^{13}$ It is worth noting that the findings summarized in Table 1 suggest a positive impact of government tax revenues and a negative impact of social security expenditures.
} 
Using a novel country-industry level panel database with data on firm entry in 17 European countries over the period 1997-2004, Da Rin et al. (2010) examine the relationship between entrepreneurship, firm entry, and the taxation of corporate income. The authors obtain evidence in support of a significant negative effect of corporate income taxation on entry rates. Moreover, they find that the effect is concave, suggesting that tax cuts affect entry rates only below a certain threshold tax level. A negative relationship between taxes and self-employment was also obtained in Hansson (2010) using data from Sweden. Hansson studies the relationship between income taxes and the decision to become self-employed using data from Sweden and finds, in contrast to many earlier studies using US data, ${ }^{14}$ that both average and marginal taxes have a negative impact on the decision to become self-employed. Fossen and Steiner (2009) examine the impact of income taxes on entrepreneurial choice based on evidence from two German natural experiments. The authors report that marginal tax rates have a negative effect on SMEs. Similarly, Stabile (2004) who uses Canadian micro-level data for the period 19901996 finds that a higher marginal tax has a negative effect on the decision to be self-employed. However, he finds a positive effect from higher pay-roll taxes on employees. On the other hand, Parker (1996) and Bruce (2000) find a positive effect from marginal tax rates, while Georgellis and Wall (2006) report a U-shaped relationship between marginal tax rates and entrepreneurship. Robson (1998) and Gentry and Hubbard (2004a) did not find a statistically significant effect of marginal tax rates on entrepreneurship. Oddly, the bulk of the empirical evidence on the impact of average tax rates points to a positive effect on entrepreneurship (self-employment). This difference in the effects of average and marginal tax rates suggests that tax progressivity may play an important role.

Another way to study the effects of taxes on entrepreneurship is by focusing on the impact of a tax change on the degree of risk-taking. For example, using data from the US personal income tax returns over the period 1964-1993, Cullen and Gordon (2007) examine the effects of the tax system on the amount of entrepreneurial risk-taking (where higher risk-taking is proxied by higher business losses (when annual expenses exceed revenues). Interestingly, Cullen and Gordon find that the nature of the impact of taxes on entrepreneurial risk-taking depends on the kind of tax. This is because there are several types of taxes that may affect entrepreneurship,

\footnotetext{
${ }^{14}$ See, for instance, Cullen and Gordon (2007) quoted below.
} 
including personal income tax, payroll tax, and capital gain tax. The authors find, for example, that allowing a deduction of business losses on personal income-tax return would raise entrepreneurial risk-taking by $50 \%$ to $100 \%$, while reducing personal tax rates by 5 percentage points, across income brackets, would reduce entrepreneurial risk-taking by about $40 \%$. Along these lines, there is an important empirical literature on how taxes affect start-ups and the success of enterprises that are financed by venture capital (Gompers and Lerner, 1998; Keuschnigg and Nielsen, 2004; Bruce and Mohsin, 2006). The bulk of the evidence points to a negative link between venture capital funding and taxes. For example, based on an empirical study using data from 14 European countries over the period 1988-2001, Da Rin et al. (2006) report that lowering capital gains tax, reducing labor regulations, and opening a new venture stock market are the three most effective policies to raise the proportion of high-tech and earlystage ventures. Using US data Bruce and Mohsin (2006) find that reducing the capital-gains tax rate by 1 percentage point is associated with an increase from 0.11 to 0.15 percentage points in self-employment rates.

\subsection{Tax progressivity and entrepreneurial activity}

While there is a relatively important body of theoretical literature on the topic of tax progressivity, the empirical literature is remarkably scant. Theoretical models predict, on the basis of micro-level data, ambiguous tax progressivity effects on entrepreneurship. This does not come as a total surprise since. As noted earlier, tax progressivity can lower entrepreneurship via the 'incentives' effect (reducing the size of profit opportunity). It can also lead to an increase in nascent entrepreneurship if risk-averse entrepreneurs perceive it as an insurance mechanism - by providing loss offsets or because of lower rate in case of failure - or if it makes tax avoidance (or tax evasion) easier for the self-employed (Gordon, 1998; Gentry and Hubbard, 2000; Gentry and Hubbard 2004a).

Asoni and Sanandaji (2009) show that "even with risk-neutral agents and no tax evasion, progressive taxes can increase entrepreneurial entry, while reducing average firm quality." In contrast, Gentry and Hubbard (2000) did not find evidence to support such channels and conclude that their empirical results "imply a significant increase in entrepreneurial entry when 
tax rates are less progressive; whether such encouragement is efficient (that is, stimulating the most talented entrepreneurs) is a topic for future research" Gentry and Hubbard (2000, p. 286).

To our knowledge, there is, however, no study examining the effects of tax progressivity on entrepreneurship using macro-level data. Recent work on tax progressivity and entrepreneurship includes the four studies listed on Table 1. Gentry and Hubbard (2000) use US micro-level data over the period 1979-1992 and examine the effects of tax progressivity on entry in self-employment by head of household. The main control variables were education, opportunity cost (wage earned), and age (experience). The authors measure progressivity by the convexity of the tax schedule. Convexity is measured by taking the difference between the marginal tax rate that will apply to the household's income if the self-employed member of the household is successful and the marginal tax rate that would apply if the self-employed is unsuccessful (Gentry and Hubbard, 2000). ${ }^{15}$ Their results indicate that both the marginal tax rate and progressivity discourage entry in self-employment while the average tax rate encourages it.

The second study is Gentry and Hubbard (2004a), which also uses US micro-level data. The authors conclude that "[p]rogressive marginal tax rates discourage entry into self-employment and business ownership. Those effects are large: The Omnibus Budget Reconciliation Act of 1993, which raised the top marginal individual income tax rate, was estimated to have reduced the probability of entry into self-employment for upper middle income households by as much as $20 \% "$ (Gentry and Hubbard, 2004a:2).

The third study - also by the same authors (Gentry and Hubbard, 2005)-examines whether the entrepreneurs that are kept "out of business" by progressive taxation are the most innovative ones. Indeed (see the discussion above), many parameters influence the decision to behave in an entrepreneurial way and the most innovative entrepreneurs could well be those who are less sensitive to change in tax policy. If this is so, it would mean that although tax

\footnotetext{
${ }^{15}$ More precisely, they build two scenarios: in one of them success means that the income of the self-employed is twice her previous income while lack of success reduces income to $50 \%$ of what it previously was. They then look at the two corresponding marginal income tax rates. In the second scenario, success increases income to $150 \%$ of what it was while failure reduces it to $75 \%$ of its previous level.
} 
progressivity affects entrepreneurial entry, it has a limited impact on growth. ${ }^{16}$ It is not possible to observe from the data what types of entrepreneurs respond more strongly to an increase in the convexity of the tax schedule. The authors reach an indirect estimation by assuming that higher education, technical industries and occupations are more likely to be linked to 'innovative entrepreneurship'. The overall result is that there is no evidence that prospective innovative entrepreneurs are differently affected by tax convexity.

Finally, Bacher and Brülhart (2010) use Swiss micro-level data and examine the effect of corporate income tax schedule on firm births. More precisely, they disentangle three effects: effect of the average level of taxation, effect of the degree of progressivity, and effect of the complexity of the system. Their main finding is that high average tax and complicated tax code reduce the rate of firm births, but progressivity can increase it. The latter effect is, however, of relatively low importance compared to the first two.

In addition, Gentry and Hubbard (2004b) examine the effects of progressive income taxation on job mobility in the U.S., using data from the Panel Study of Income Dynamics. Their estimates imply that a five-percentage-point reduction in the marginal tax rate increases the average probability of moving to a better job by 0.79 percentage points and that a onestandard-deviation decrease in tax progressivity raises this probability by 0.86 percentage points. The authors conclude that their "estimated importance of tax policy for job turnover suggests a potential role in explaining the responsiveness of taxable income to marginal tax rates."

Note that the convexity of the tax schedule can be due to progressive marginal rates-what the literature has focused on-or to other features of the fiscal system such as loss offset rules or tax credit for research and development. Hence, although incorporated businesses pay a flat corporate tax, imperfect loss offset might introduce some non-linearity (Gentry et al. 2005:92). ${ }^{17}$

\footnotetext{
${ }^{16}$ However, such a link between innovation and growth should not be exaggerated. An entrepreneur who imitates some previous innovation can enhance general well being as much as a 'pure' innovator.

${ }^{17}$ Also, tax credit for research could introduce a bias in investment decisions. But it can also have no impact in the sense that the investment would have been made independently from the fiscal policy.
} 
Thus, the net effects of tax progressivity are ambiguous in theory and the empirical evidence is mixed, which warrants further empirical investigation. In this paper, we follow Gentry and Hubbard (2000 and 2004a) and try to extend their framework using aggregated (macro) data, in the sense that we measure tax progressivity by the difference in marginal and average tax rates at different levels of income. In the next section, we describe the indicators of entrepreneurship (the dependent variable) and the explanatory variables we use in the various estimations. We also present the methodology we employ in the empirical analysis.

\section{Variables and methodology}

\subsection{Variable description}

The dependent variable is entrepreneurship, represented by the rate of nascent entrepreneurship (GEM-nascent) from the Global Entrepreneurship Monitor database. The right-hand-side (RHS) variables of primary interest are the tax variables (tax rates and tax progressivity). We control for the effect of income per capita (in log) and start-up cost. We treat these two variables, as well as the tax variables, as endogenous because of potential two-way causality between them and the indicators of entrepreneurship (the dependent variable). ${ }^{18}$ We also control for several other potential determinants of entrepreneurship, including two measures of the level of human capital (school enrolments at the secondary and tertiary levels), indicators of financial development (domestic credit to private sector as \% of GDP) and the quality of credit information (credit depth of information), unemployment rates, and risk, proxied by the ICRG investment profile component (see Appendix B). In later estimations (Tables 5 and 6), we also include inflation, government expenditure and subsidies.

The time period under study is $2000-2008$ and the panel is unbalanced, but we included only countries that have at least five years of data for each of the indicators of entrepreneurship,

\footnotetext{
${ }^{18}$ The issue of endogeneity of taxes has been raised in the empirical literature using micro-level data (e.g., Bruce 2000; Stabile 2004). However, we think endogeneity may also be a problem in macro-level data if policymakers respond to shocks in levels of entrepreneurship by altering next period's tax structure. Note that treating the tax variables as exogenous does not change the magnitude or significance of the results.
} 
which puts a limit on the number of countries. Our sample has 15 European countries: Belgium, Denmark, Finland, France, Greece, Hungary, Iceland, Ireland, Italy, Netherlands, Norway, Slovenia, Spain, Sweden, and the United Kingdom. ${ }^{19}$ A more detailed data description is provided in Appendix B.

The summary statistics shown in Table 2 suggest the presence of wide disparities among the 15 countries in most of the variables of interest (see also Figures 2 and 3). For example, the percentage of nascent entrepreneurs in 18-64 population ranges from a minimum of $1.7 \%$ (Sweden in 2004 and 2005, and Netherlands in 2003) to a maximum of 8.5\% (Iceland in 2007). The net personal average tax rate (at $100 \%$ of average earnings in the country) ranges from $16.5 \%$ (Greece in 2001) to $44.2 \%$ (Denmark in 2000), while the net personal marginal tax rate varies from 20.1\% (Greece in 2001) to 69.2\% (Hungary in 2004 and 2005). Similarly, the tax wedge based on average tax rates ranges from $26.16 \%$ (Iceland in 2000) to 56.66\% (Belgium in 2000).

\subsection{Estimation technique}

We estimate a model specified by the following equation.

$y_{i t}=\alpha y_{i t-1}+\beta x_{i t}+\mu_{i}+\varepsilon_{i t}$

Where $y_{i t}$ is entrepreneurship in country $i$ at time $t, \alpha$, and $\beta$ are parameters to be estimated, and $x_{i t}$ is a vector of explanatory variables. The term $\mu_{i}$ represents country-specific random effects which are independent and identically distributed over the countries. The term $\varepsilon_{i t}$ is independent and identically distributed, and $\mu_{i}$ and $\varepsilon_{i t}$ are assumed to be independent over all time periods and for each country $i$. The tax variables as well as income and start-up costs are treated as endogenous. The model is estimated using the Arellano-Bond dynamic Generalized Method of Moments (GMM) estimator (Arellano and Bond, 1991). ${ }^{20}$

\footnotetext{
${ }^{19}$ Germany is excluded due to the lack of data on tertiary education in the World Bank Word Development Indicators database.

${ }^{20} \mathrm{We}$ also estimate the model using OLS on pooled data (with robust standard errors). We report the results in Appendix A and discuss them briefly in Section 4.
} 
In order to take into account the possible endogeneity of taxes, income, and the start-up cost we use the Arellano-Bond dynamic GMM estimator. One of the advantages of this estimator is that it helps eliminate unobserved individual specific effects by first-difference equation (1) to get

$y_{i t}-y_{i t-1}=\alpha\left(y_{i t-1}-y_{i t-2}\right)+\left(x_{i t}-x_{i t-1}\right)^{\prime} \beta+\left(\varepsilon_{i t}-\varepsilon_{i t-1}\right)$

We can see that the term $\left(y_{i t-1}-y_{i t-2}\right)$ in this equation is correlated with the error term $\left(\varepsilon_{i t}-\varepsilon_{i t}\right)$ and, as noted earlier, the vector $x$ may contain endogenous variables. Thus, we need to use instruments to control for this endogeneity problem. ${ }^{21}$ The Arellano-Bond instruments the differenced right-hand-side variables with their appropriately lagged levels and this allows us to tackle the issue of endogeneity. ${ }^{22}$

We assume that entrepreneurs move from a current wage income to a higher income either from lower than average (67\% of average earnings) to $100 \%$ of average income or from average income to much higher income (167\% of average earnings). In contrast to many existing studies (primarily based on micro-level data), we ignore the case of failure that would occur when moving from employee income level (when individuals are employed and receive wage income) to much lower earnings as entrepreneurs. Thus, the assumption here is that individuals plan to be entrepreneurs and expect a higher income from entrepreneurship (relative to wages), which would change their marginal and average tax rates. Then, we proceed to examine how an increase in marginal and average tax rates, as well as tax progressivity, affect entrepreneurship —nascent entrepreneurs in particular.

\footnotetext{
${ }^{21}$ We perform tests for second-order autocorrelation (results are omitted to save space but may be obtained from the authors) and the Sargan test of overidentifying restrictions. The test results indicate that all the reported estimations pass both tests.

${ }^{22}$ In addition, the Arellano-Bond GMM estimator was designed for small $\mathrm{T}$ and large $\mathrm{N}$ panels. In our sample, $\mathrm{T}$ (number of years) varies between 5 and 9 .
} 


\section{Estimation results}

First, we perform pooled-panel data estimations and report the results in Table A1 in Appendix A. The results suggest that (after controlling for several relevant variables) there is a strong negative relationship between average and marginal tax rates (net personal average tax rate and net personal marginal tax rate, respectively) and entrepreneurship (also see Figure 4). On the other hand, the relationship between entrepreneurship and tax progressivity seems to depend on the level of income. There is a positive effect of progressivity at marginal tax rates associated with incomes up to $100 \%$ of average earnings (progressivity_1) but a statistically nonsignificant negative effect of progressivity at higher income (progressivity_2). However, these estimates do not take into account the possible endogeneity of tax rates, income, and the cost of starting a business. As noted earlier, the Arellano-Bond dynamic panel GMM estimator allows us to tackle the problem of endogeneity.

The main focus in Table 3 is on the effect (on the dependent variable; i.e., entrepreneurship) of the tax variables net personal average and net personal marginal tax rates for a single person at $100 \%$ of average earnings in her country. ${ }^{23}$ We also control for several main variables based on our previous discussion. As noted earlier, the variable start-up cost represents the cost of business startup procedures measured by the cost to register a business (normalized by making it a percentage of gross national income per capita). ${ }^{24}$ This variable as well as per-capita income (in log), and the tax variable are treated as endogenous given that they may be affected by the level of entrepreneurial activity in the country. The other control variables are treated as exogenous. The estimates in Table 3 indicate that net personal average tax rate (at $100 \%$ of average earnings) has a positive effect that is marginally significant (at the 10-percent level), while net personal marginal tax rate has no significant impact. The three variables that show evidence of significance (with correctly signed coefficients) in both equations are tertiary education, credit depth of information, and start-up cost.

\footnotetext{
${ }^{23}$ We also use net personal average (and marginal) tax for a single person at $67 \%$ and $167 \%$ of average earnings (not shown) and the results are very similar to the ones reported in Table 3.

${ }^{24}$ We used four alternative indicators of the cost in time and procedures to start a business, including number of procedures to enforce a contract, number of procedures to register property, number of days to enforce a contract and number of days register property but they all turned out to be mostly nonsignificant. Thus, we omitted those results.
} 
Since a primary goal of this paper is to explore the effect of tax progressivity we construct an indicator of progressivity of the tax schedule following Gentry and Hubbard (2000 and 2004a), who use micro-level data and measure convexity (progressivity) by differences in the marginal tax rates at different levels of income. The authors also use average tax rates and their differences as an alternate measure of progressivity. We acknowledge that a measure based on differences in tax rates may be better suited for micro-level data. However, we believe that applying this measure to aggregate data can provide some useful insights, particularly when using panel data from a number of countries. In order to enhance the applicability of this measure (difference between tax rates), we construct two measures of progressivity based on marginal tax rates and two measures of progressivity based on average tax rates. The two measures of progressivity can be interpreted as the 'downside' (progressivity_1) and the 'upside' (progressivity_2) progressivity (Gentry and Hubbard, 2004a). ${ }^{25}$ The first measure (progressivity_1) is the difference between the marginal tax rate for a single person at $100 \%$ of average earnings in her country and her marginal tax rate at $67 \%$ of average earnings. The second (progressivity_2) is measured by the difference between the marginal tax rate for a single person at $167 \%$ of average earnings and the marginal tax rate at $100 \%$ of average earnings. We use the same method to obtain progressivity measures of average tax rates.

Table 4 reports the results from estimations using progressivity indicators, in addition to all the RHS variables shown in Table 3. The results in columns (1) and (2) of Table 4 indicate that progressivity (based on differences in marginal tax rates) matters for nascent entrepreneurs. The results suggest that an increase in tax progressivity on incomes in the range of low-toaverage earnings (from $67 \%$ to $100 \%$ of average earnings) and in the range of average-to-high income (from $100 \%$ to $167 \%$ of average earnings) discourages entrepreneurial activity as measured by the variable GEM-nascent.

We re-estimate these two equations substituting average income tax rate and the progressivity of net personal average tax rate for net personal marginal tax rate and its progressivity. The results in columns (3) and (4) of Table 4 show that progressivity based on a lower income

\footnotetext{
${ }^{25}$ More accurately, 'downside' convexity in Gentry and Hubbard (2004a) refers to the case of failure. Here we use it to refer to lower levels of success or no improvement in income (relative to wage income).
} 
range (from $67 \%$ to $100 \%$ of average earnings) has no significant impact while progressivity_2 (from $100 \%$ to $167 \%$ of average earnings) has a negative and statistically significant impact on nascent entrepreneurship (GEM-nascent).

We conduct several robustness checks and report the results in Tables 5 and 6. First, we control for the extent of subsidies ( $\%$ of government expenditure) and government expenditures (general government final consumption expenditure), and we also examine the effect of inflation. We treat subsidies and government expenditure as endogenous variables. The results in columns (2) and (4) of Table 5 indicate that progressivity_2 (based on net personal average tax rates) has a negative and significant effect on nascent entrepreneurship, while progressivity_1 (income at $67 \%$ to $100 \%$ of average earnings) is statistically significant and has a positive effect when we control for government expenditures (column 3).

Second, we replace the tax variables by tax wedges. According to OECD, a tax wedge measures "the difference between what employers pay out in wages and social security charges and what employees take home after tax and social security deductions plus any cash benefits for which they may be eligible." ${ }^{26}$ Increases in tax wedges can be a significant disincentive to work. If the 'insurance' effect of self-employment dominates we may see an increase in new self-employment as the wedge increases. On the other hand, if the 'success' effect dominates we would see a decline since an increase in the tax wedge would discourage new selfemployment. The results in Table 6 suggest that progressivity_1 (based on net personal average tax rates) has a positive effect in all cases (columns 1, 3 and 5), while progressivity_2 has a strong negative effect in all cases (columns 2, 4 and 6). Thus, the empirical evidence on the negative impact of tax progressivity (as defined in this paper), at incomes higher than average ( $167 \%$ of average earnings in the country), is remarkably robust. The results associated with the impact of tax progressivity at lower income levels (progressivity_1) are slightly mixed but in general point to a positive impact. We find that progressivity_1 has a negative and statistically significant impact on nascent entrepreneurship only when we base our measure of progressivity on differences in net personal marginal tax rates (column 1 of Table 4), otherwise

\footnotetext{
${ }^{26}$ See, for example, Taxing Wages 2009-2010 Special feature: Wage income tax reforms and changes in tax burdens (www.OECD.org).
} 
the effect is shown to be positive and statistically significant for the most part (Tables 5 and 6). We also note that the positive effect of tertiary education and the negative effects of business start-up cost and subsidies are robust. Overall, the empirical evidence on the contribution of the other control variables is either not robust or statistically nonsignificant.

\section{Summary and discussion}

This paper makes a novel contribution to the literature by being the first study to use European macro-level panel data and explore the effects of taxes and tax progressivity on existing entrepreneurial activity and nascent entrepreneurship using diverse measures of taxation.

The Arellano-Bond dynamic GMM estimation results provide ample evidence that tax progressivity discourages entry into entrepreneurship (nascent entrepreneurs) among those with high incomes while it seems to encourage entrepreneurship when incomes are low-to-average. We find that the average and marginal tax rates do not seem to have a robust impact. Our results are consistent with previous studies focusing on the U.S. (using micro-level data) that have reported a negative effect from tax progressivity on entrepreneurial activity (Gentry and Hubbard, 2000, 2004a and 2005) but are in stark contrast with Bacher and Brülhart (2010) who find a positive effect of tax progressivity using micro-level data from Switzerland. Concerning the effects of average and marginal tax rates, our findings seem to be consistent with the existing literature-which contains mixed evidence on these effects.

The empirical results suggest that reducing tax progressivity within the range of high income (between 100\% and 167\% of average earnings) would have a positive and significant effect on nascent entrepreneurship (see Figure 5). The results in Table 6, suggest that a 1-unit reduction in progressivity (of tax wedges) at high levels of income (progressivity_2) would increase the rate of nascent entrepreneurship by approximately 0.4 to 0.5 units. Similarly, the results in column (4) of Table 4 suggest that a 1-unit reduction in progressivity_2 would increase the rate of nascent entrepreneurship by about 0.35 units. As an illustration, consider for example Ireland which, in 2008, had a rate of nascent entrepreneurs equal to $3.3 \%$ and the second 
highest value for progressivity_2 (10.32), behind Sweden. Using the results in column (4) of Table 4 and assuming no change in the 2008 tax rate (at $100 \%$ of average earnings), a reduction of $50 \%$ in progressivity_2 in Ireland requires that the net average personal tax rate for a single individual at $167 \%$ of average earnings be reduced from its 2008 level of $29.274 \%$ to $24.114 \%$. In this case, Ireland will see its rate of nascent entrepreneurship increase by 1.8 units, from 3.3 to $5.1 \%$.

It is also important to note that a significant portion of entrepreneurial activity in Europe tends to start at income higher than the average income. For example, in countries such as France, $67 \%$ of average income is close to minimum wage. This suggests that what matters is the upper range (progressitivy_2) because entrepreneurs do not normally start a business with the idea of reaching average income.

The results associated with the progressivity of tax rates may be interpreted in a number of ways. ${ }^{27}$ These results could imply that the 'insurance' effect dominates around average earnings, in the sense that entrepreneurs may not be wealthy and view tax progressivity (higher tax rates) perhaps as not strictly applicable to them either because their income would not reach those tax ranges or it may be easier for them, than it is for successful entrepreneurs, to hide part of their income from tax agents (legally or illegally). The positive impact of tax progressivity in the lower income is also consistent with the 'success' effect since the lower income range implies less success. On the other hand, the negative impact of progressivity_2 implies that tax progressivity at higher income levels discourages entry into entrepreneurship. Since we assume that successful entrepreneurs would end up in this income range, the results suggest that the 'success effect' dominates. This can have important policy implications, particularly when we consider the type of entrepreneurship that would have the most significant impact on innovation and growth.

\footnotetext{
27 At a theoretical, micro-level, the study of the impact of taxation on entrepreneurship partly resembles the study of the impact of a change in wages on the supply of labor; with similar conclusions. It is well known, indeed, that lower wages can lead employees to reduce or to increase their supply of labor according to which of the substitution effect (leisure is more attractive when wages are lower) or the income effect (the need to work more to maintain a certain purchasing power) dominates. The same reasoning applies to entrepreneurship, taxation being equivalent to a wage reduction.
} 
Before drawing policy conclusions, a few additional remarks are in order. First, it is important to note that taxation is only one of the parameters in the individual's decision to undertake an entrepreneurial activity. If, for instance, a jurisdiction introduces very low flat tax on all forms of income (personal, corporate, capital gain, etc.) but maintains an intrusive level of regulation, or if the new flat tax policy can be changed at any moment, then the entrepreneur might choose to invest her talent in activities that are less sensitive to adverse changes in fiscal policy or in regulation (or perhaps she may leave the jurisdiction for a more predictable one). We should also keep in mind that established or potential entrepreneurs consider the fiscal system in its entirety. Empirical studies, however, tend to focus on tax rates - often exclusively on personal income tax rates or corporate tax rates. ${ }^{28}$ However, the entrepreneur compares various forms of legal status and might choose to leave a status of self-employed and incorporate her business if the comparison between corporate and personal income taxes makes it more desirable. ${ }^{29}$ By controlling for the effects of subsidies and government expenditures (Tables 5 and 6), our study indirectly takes this dimension into account. Finally, most fiscal systems have developed complex rules such as loss-recovery, or lump-sum tax for new businesses that might push the entrepreneur into one type of legal status or another. These remarks are important given that most empirical studies on taxation and entrepreneurship take the proportion of self-employed in the working population as a proxy for the level of entrepreneurship. Behind the choice of self-employment there might be reasons other than the desire to start a new business in order to grasp a new profit opportunity. ${ }^{30}$

\footnotetext{
${ }^{28}$ While it is not possible to account for all relevant taxes using macro-level data, we have tried to consider other taxes and contributions that create a wedge between gross income and net income by including tax wedges.

${ }^{29}$ Low taxation of capital gain can also promote entrepreneurship to the extent that (i) the entrepreneur can report part of the profits as capital gains and (ii) financing through venture capital will be available at lower cost. Also, what will be reported as corporate income and what will be reported as personal income obviously depends on how the respective rates compare. See Bacher and Brülhart (2011: 4).

${ }^{30}$ Self-employment increases opportunities for tax evasion (e.g., it is easier to hide part of business income) and tax avoidance (e.g., deduction of business related consumption). Those strategies receive sometimes the name of "tax-sheltering". This could explain why higher marginal income tax rates are often associated with an increase of self-employment at least for high-income brackets (see Schuetze, 2000, and Bruce 2000 and 2002). Hence, tax sheltering could explain what is happening in France where a new legal statute for self-employed was created by law on August $4^{\text {th }} 2008$, and has been implemented since January $1^{\text {st }} 2009$. A 'self-entrepreneur' (in French, autoentrepreneur) avoids paying corporate tax and social taxes and pays only a single flat tax (13\% of turnover if the activity consists in selling goods, $23 \%$ if selling services). Also, the amount of red tape was reduced relatively to what an 'ordinary' business has to face. As a consequence, the number of 'new entrepreneurs' soared in the following years to exceed half a million in 2011.
} 
Despite these warnings, it is clear that the evidence derived in this study does not support current fiscal policies. Following the recent economic and financial crises and the associated threat to employment, governments have often chosen to alter the tax structure by introducing new taxes or increasing marginal tax rates, instead of cutting government spending. ${ }^{31}$ This study sheds strong doubts on the appropriateness of those choices. Several European countries, including Denmark, France, Italy, Norway and Sweden experienced a decline in the share of tax revenues in GDP from 2008 to 2009 (see IREF 2010) and, if we are correct, the fiscal response may not be able to reverse that trend and growth and unemployment may continue to be disappointing.

All in all, it is not clear that governments should take the opposite direction and engage in positive discrimination in favor of start-ups or new businesses. It is possible that the best strategy would involve more fiscal neutrality. Low progressivity, or even a flat tax, might be part of such strategy but it is also important to reduce the global fiscal burden and start-up costs. To get a better understanding of the best tax structure in terms of long-term growth, it will be interesting to leave the realm of macro- and micro-studies focusing on some specific taxes and to turn towards case studies that would allow a deeper look at the interactions between the various parameters of a given fiscal policy.

\footnotetext{
${ }^{31}$ This temptation has become more acute after the recent crisis, since public opinion believes that high-income earners have actually been the main beneficiaries of the bail-out programs financed by the rest of the population.
} 


\section{References}

Alesina, A. and S. Ardagna (2009). "Large changes in fiscal policy: Taxes versus spending." NBER working paper 15438.

Arellano, M., and S. Bond (1991). "Some tests of specification for panel data: Monte

Carlo evidence and an application to employment equations." The Review of Economic Studies, $58,277-97$.

Asoni, A. and T. Sanandaji (2009). "Taxation and the quality and quantity of entrepreneurship.” IFN WP no. 813.

Bacher, H. U. and M. Brülhart (2010). "Progressive taxes and firm births." Working paper. CEPR DP7830 (www.cepr.org/pubs/dps/DP7830.asp).

Baliamoune-Lutz. M. (2007). "Entrepreneurship, reforms, and development: Empirical evidence.” International Centre for Economic Research (ICER) Working Paper no. 38, 2007.

Baliamoune-Lutz. M. (2010). "Policy reform and entrepreneurship in developing countries." Chapter 9 in Naudé, W.A. ed., Entrepreneurship in Economic Development. Palgrave Macmillan.

Baumol, W. J. (1990). "Entrepreneurship: Productive, unproductive and destructive." Journal of Political Economy, 98(5):893-921.

Bruce D. (2000). "Effects of the United States tax system on transitions into self-employment." Labour Economics, 7(5): 545-74.

Bruce D. (2002). "Taxes and entrepreneurial endurance: Evidence from the self-employed." National Tax Journal, 55(1): 5-24. 
Bruce, D., and M. Mohsin (2006). "Tax policy and entrepreneurship: New time series evidence. Small Business Economics, 16, 409-425."

Carroll, R., Holtz-Eakin, D., Rider, M., and Rosen, H. S. (2000). "Income taxes and entrepreneurs' use of labor." Journal of Labor Economics, 18(2), 324-351.

Carroll, R., D. Holtz-Eakin, M. Rider, M., and H. S. Rosen (2001). "Personal income taxes and the growth of small firms." In Tax Policy and the Economy, Vol. 15, edited by James Poterba, 121-47. Cambridge, MA: MIT Press, 2001.

Colombatto, E., and A. Melnik (2008). "Founders and funders: An introduction to entrepreneurship and venture capital." New Perspectives of Political Economy, 4, 1-21.

Cullen, J. and R. Gordon (2007). "Taxes and entrepreneurial risk-taking: Theory and evidence for the US." Journal of Public Economics, 91, 1479-1505.

Da Rin, M., G. Nicodano, and A. Sembenelli (2006). "Public policy and the creation of active capital markets." Journal of Public Economics, 80, 1699-1723.

Da Rin, M, M. Di Giacomo, and A. Sembenelli (2010). "Entrepreneurship, firm entry, and the taxation of corporate income: Evidence from Europe." Journal of Public Economics, doi:10.1016/j.jpubeco.2010.06.010

Domar, E. and R. Musgrave (1944) "Effects of proportional taxes on risk-taking." Quarterly Journal of Economics 58, 388-422.

Fossen, F. and V. Steiner (2009). "Income taxes and entrepreneurial choice: Empirical evidence from two German natural experiments." Empirical Economics, 36, 487-513.

Fritsch, M. (2011). "New business formation and regional development-A survey and assessment of the evidence." Deutsches Institut für Wirtschaftsforschung, Discussion papers, 1127, Berlin 
Gentry, W. M., and R. G. Hubbard (2000). "Tax policy and entrepreneurial entry.” American Economic Review 90, 2, 283-87.

Gentry, W. M., and R. G. Hubbard (2004a). "Tax policy and entry into entrepreneurship, Mimeo, Williams College.

Gentry, W. M., and R. G. Hubbard (2004b). "The effects of progressive income taxation on job turnover." Journal of Public Economics, 88, 2301- 2322.

Gentry, W. M., and R. G. Hubbard (2005). “' 'Success taxes', entrepreneurial entry and innovation.” In: Jaffe, Adam B., Josh Lerner and Scott Stern (eds.) Innovation Policy and the Economy - Volume 5, NBER and MIT Press.

Georgellis, Y. and H. J. Wall (2006). "Entrepreneurship and the policy environment." Review, Federal Reserve Bank of St. Louis, March, 95-112.

Gompers, P.A. and J. Lerner (1998). "What drives venture capital fundraising?" Downloaded from http:/www.hbs.edu/research/facpubs/workingpapers/papers2/9899/99-079.pdf

Gordon, R. H. (1998). "Can high personal tax rates encourage entrepreneurial activity?" International Monetary Fund Staff Papers, 45, 49-80.

Gurley-Calvez, T. and D. Bruce (2009). "Do tax rate cuts encourage entrepreneurial entry?" Downloaded from http://web.utk.edu/ dbruce/entry.209.pdf

Hansson, Å. (2010, forthcoming). "Tax policy and entrepreneurship: empirical evidence from Sweden." Small Business Economics, DOI: 10.1007/s11187-010-9282-7.

Haufler, A. and G. Schjeledrup (2000).“Corporate tax systems and cross-country profit shifting." Oxford Economic Papers, 52, 306-325. 
Keuschnigg, C. and S. B. Nielsen (2002)."Tax policy, venture capital, and entrepreneurship.” Journal of Public Economics, 87, 175-203.

Kitao, S. (2008). "Entrepreneurship, taxation and capital investment." Review of Economic Dynamics 11(1): 44-69.

Mendoza, E. G., G. M. Milesi-Ferretti, and P. Asea (1997). "On the ineffectiveness of tax policy in altering long-run growth: Haberger's superneutrality conjecture." Journal of Public Economics, 66, 99-126

Parker S.C. (1996). “A time series model under uncertainty.” Economica, 63(251): 459-75.

Parker, S. C. (2003). "Does tax evasion affect occupational choice?" Oxford Bulletin of Economics and Statistics, 65(3), 379-394.

Parker, S. C. and M. T. Robson (2004). "Explaining international variations in selfemployment: Evidence from a panel of OECD countries." Southern Economic Journal, 71(2), $287-301$.

Robson, M. T. (1998). "The rise in self-employment amongst UK males.” Small Business Economics, 65, 757-773.

Robson, M. T. and C. Wren (1999). "Marginal and average tax rates and the incentives for selfemployment." Southern Economic Journal, 65(4), 757-773.

Schuetze, H. J. (2000). "Taxes, economic conditions and recent trends in male selfemployment: A Canada-U.S. comparison.” Labour Economics, (7)5: 507-44.

Stenkula, M. (2010, forthcoming). "Taxation and entrepreneurship in a welfare state." Small Business Economics, DOI 10.1007/s11187-010-9296-1. 
Stabile, M. (2004). "Payroll taxes and the decision to be self-employed." International Tax and Public Finance, 11, 31-53.

van Stel, A., S. Wennekers, R. Thurik, and P. Reynolds (2004). "Explaining variation in nascent entrepreneurship." Research Report H200401, SCALES SCientific AnaLysis of Entrepreneurship and SMEs.

Wennekers, S., A. van Stel, R. Thurik, and P. Reynolds (2005). "Nascent entrepreneurship and the level of economic development." Small Business Economics, 24, 293-309. 
Figure 1. Entrepreneurship and growth

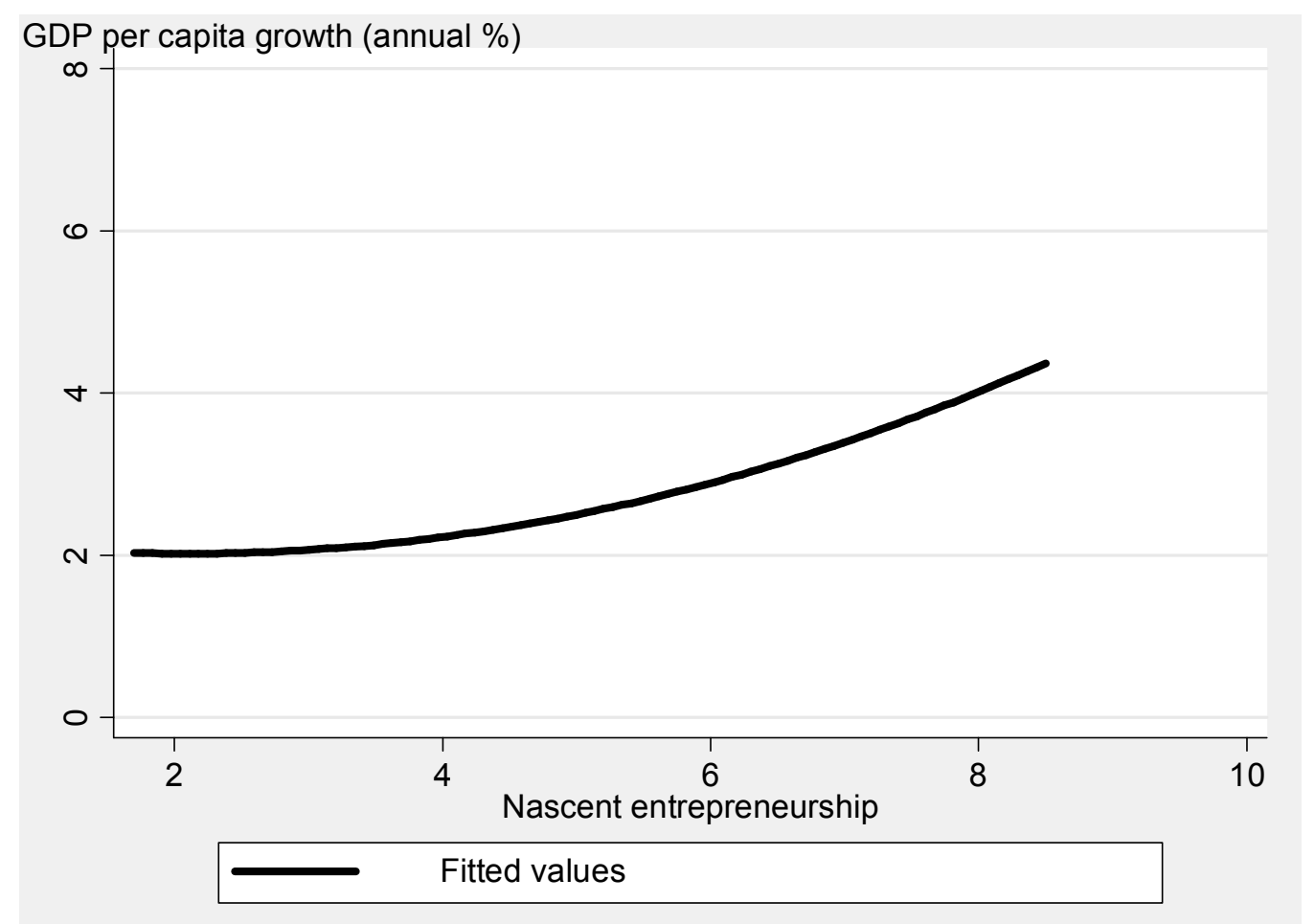

Data used to generate the graph are pooled data (2000-08) from the 15 countries covered in this study (113 observations). Nascent entrepreneurship rate (horizontal axis) is the percentage of 1864 population who are currently a nascent entrepreneur. For more details, see Appendix B. 
Figure 2. GEM - Nascent Entrepreneurship Rate

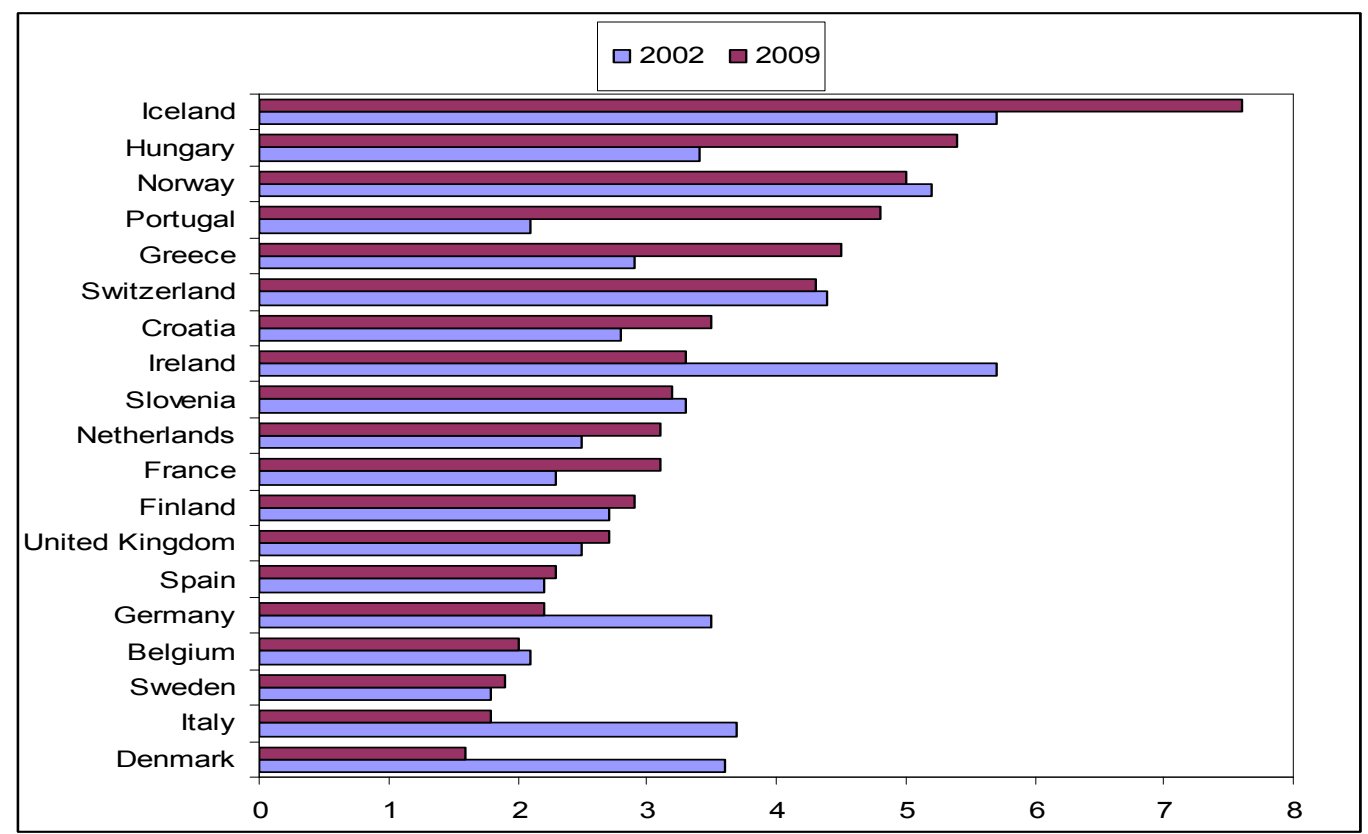

Source of data: Global Entrepreneurship Monitor database (www.gemconsortium.org).

Note: For 2002, we use data from 2001 for Portugal and from 2003 for Greece. For 2009, we use data from 2008 for Ireland and from 2007 for Portugal and Sweden. In the empirical analysis, we include only the 15 countries listed in Section 3.1.

Figure 3. GEM - Established business ownership rate

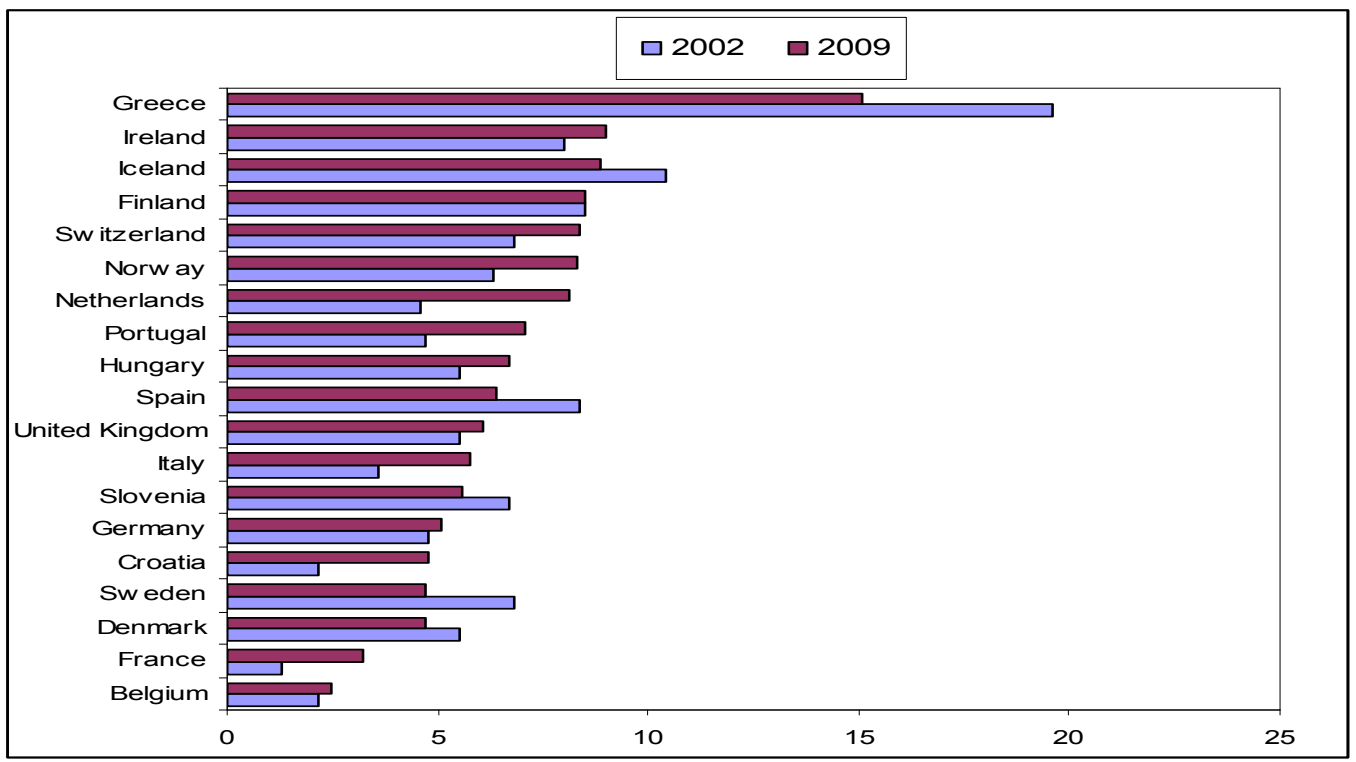

Source of data: Global Entrepreneurship Monitor database (www.gemconsortium.org)

Note: For 2002, we use data from 2001 for Portugal and from 2003 for Greece. For 2009, we use data from 2008 for Ireland and from 2007 for Portugal and Sweden. In the empirical analysis, we include only the 15 countries listed in Section 3.1. 
Figure 4. Entrepreneurship and marginal tax rates (fitted values)
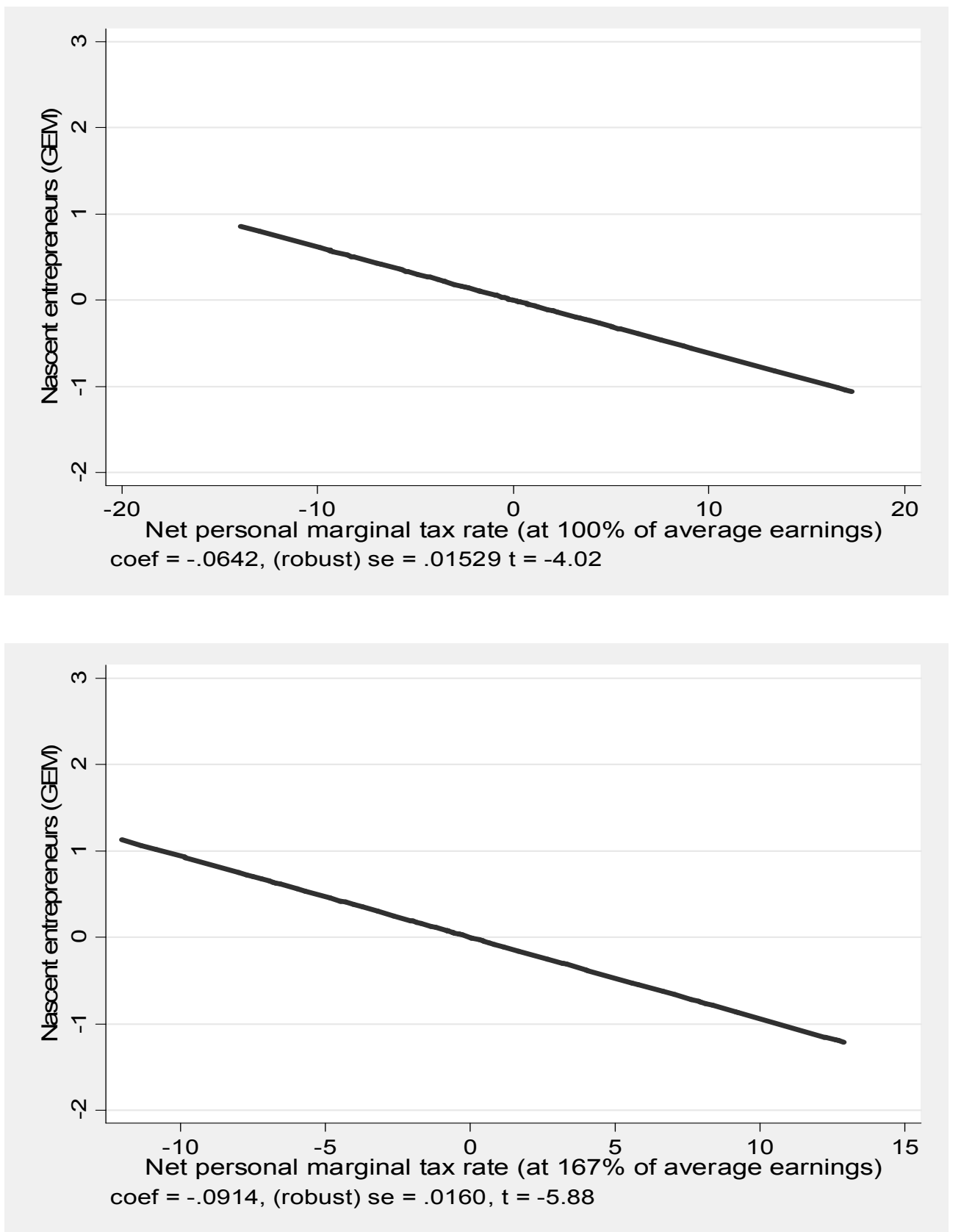

These graphs are generated from OLS estimations with nascent entrepreneurs as the dependent variable and the RHS variables in column (3) and (4) of Table A1, respectively. The graphs portray the fitted (linear) relationship (after controlling for several other explanatory variables) between nascent entrepreneurship and marginal tax rates at two different levels of income, $100 \%$, and $167 \%$ of average earnings, respectively. 
Figure 5. Entrepreneurship and tax progressivity (fitted values)
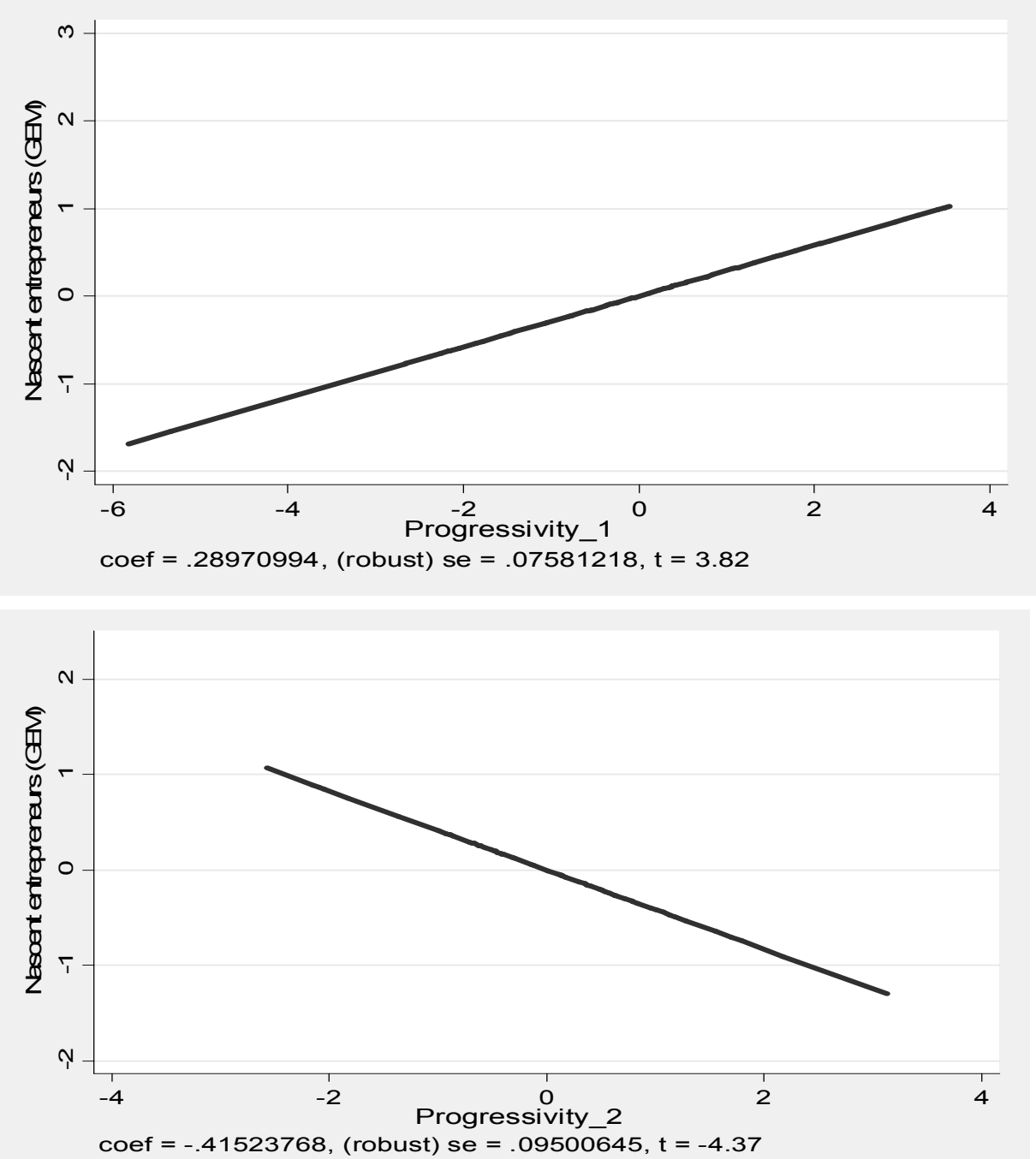

These graphs are generated from OLS estimations with nascent entrepreneurs as the dependent variable and the RHS variables in columns 3 and 4 in Table 6 . The graphs portray the fitted (linear) relationship between nascent entrepreneurship and progressivity, using tax wedges, at two different levels of income (from $67 \%$ to $100 \%$, and from $100 \%$ to $167 \%$ of average earnings, respectively), after controlling for several other explanatory variables (see Table 6). 
Table 1. Summary of recent research on entrepreneurship and taxes

\begin{tabular}{|c|c|c|c|c|}
\hline & Author & Country (countries) & Tax variable(s) & $\begin{array}{l}\text { Effect of taxes on } \\
\text { entrepreneurship }\end{array}$ \\
\hline \multirow{4}{*}{$\begin{array}{l}\text { Cross- } \\
\text { section and } \\
\text { panel } \\
\text { country } \\
\text { data } \\
\text { (macro) }\end{array}$} & $\begin{array}{l}\text { Van Stel et al. } \\
(2004)\end{array}$ & $\begin{array}{l}36 \text { countries at } \\
\text { various development } \\
\text { levels (from GEM) }\end{array}$ & $\begin{array}{l}\text {-social security expenditure cost } \\
\text { - government tax revenues }\end{array}$ & $\begin{array}{l}- \\
+\end{array}$ \\
\hline & $\begin{array}{l}\text { Parker and Robson } \\
(2004)\end{array}$ & 12 OECD & $\begin{array}{l}\text {-Average tax rate } \\
\text { - Social sec. cont. }\end{array}$ & + \\
\hline & $\begin{array}{l}\text { Wennekers et al. } \\
(2005)\end{array}$ & $\begin{array}{l}36 \text { countries at } \\
\text { various development } \\
\text { levels (from GEM) }\end{array}$ & $\begin{array}{l}\text {-social security expenditure } \\
\text { - government tax revenues }\end{array}$ & $\overline{+}$ \\
\hline & $\begin{array}{l}\text { Georgellis and } \\
\text { Wall (2006) }\end{array}$ & $\begin{array}{l}\text { USA (state aggregate } \\
\text { data) }\end{array}$ & Marginal tax rate & $\begin{array}{l}- \text { then }+ \\
\text { (U-shaped) }\end{array}$ \\
\hline \multirow{13}{*}{$\begin{array}{l}\text { Cross- } \\
\text { section and } \\
\text { panel - } \\
\text { individual } \\
\text { data } \\
\text { (micro) }\end{array}$} & Bruce (2000) & USA & $\begin{array}{l}\text { - Marginal tax rate on self- } \\
\text { employment } \\
\text { - Average tax rate on self- } \\
\text { employment }\end{array}$ & $\begin{array}{l}+ \\
-\end{array}$ \\
\hline & Schuetze (2000) & USA and Canada & Federal and local average tax & + \\
\hline & Carroll et al. 2001 & USA & $\begin{array}{l}\text { Entrepreneur's personal } \\
\text { marginal income tax (effect on } \\
\text { enterprise growth) }\end{array}$ & - \\
\hline & Parker (2003) & UK & Tax incentives & 0 \\
\hline & $\begin{array}{l}\text { Gentry and } \\
\text { Hubbard (2000) }\end{array}$ & USA & $\begin{array}{l}\text { - Marginal tax rate } \\
\text { - Average tax rate } \\
\text { - Progressivity } \\
\end{array}$ & $\begin{array}{l}- \\
+ \\
-\end{array}$ \\
\hline & $\begin{array}{l}\text { Gentry and } \\
\text { Hubbard (2004a) }\end{array}$ & USA & $\begin{array}{l}\text { - Marginal tax rate } \\
\text { - Progressivity }\end{array}$ & $\begin{array}{l}0 \\
-\end{array}$ \\
\hline & $\begin{array}{l}\text { Gentry and } \\
\text { Hubbard (2005) }\end{array}$ & USA & $\begin{array}{l}\text { - Marginal tax rate } \\
\text { - Progressivity }\end{array}$ & - \\
\hline & Stabile (2004) & Canada & $\begin{array}{l}\text {-Marginal tax rates } \\
\text {-Payroll taxes on employees }\end{array}$ & + \\
\hline & $\begin{array}{l}\text { Gurley-Calvez and } \\
\text { Bruce (2009) }\end{array}$ & USA & $\begin{array}{l}\text {-Marginal tax rates for workers } \\
\text { - Marginal tax rates for } \\
\text { entrepreneurs }\end{array}$ & $\begin{array}{l}+ \\
- \\
\end{array}$ \\
\hline & $\begin{array}{l}\text { Fossen and Steiner } \\
(2009)\end{array}$ & Germany & Marginal taxes on SMEs & - \\
\hline & $\begin{array}{l}\text { Bacher and } \\
\text { Brülhart (2010) }\end{array}$ & Switzerland & Corporate tax progressivity & + \\
\hline & Hansson (2010) & Sweden & $\begin{array}{l}\text { - Marginal tax rate } \\
\text { - Average tax rate }\end{array}$ & - \\
\hline & $\begin{array}{l}\text { Da Rin et al. } \\
(2010)\end{array}$ & $\begin{array}{l}17 \text { European countries } \\
(1997-2004)\end{array}$ & Corporate income tax & - \\
\hline \multirow[t]{5}{*}{ Time series } & Parker (1996) & UK & Marginal tax rate & + \\
\hline & Robson (1998) & UK & $\begin{array}{l}\text { - Marginal tax rate } \\
\text { - Average tax rate }\end{array}$ & $\begin{array}{l}0 \\
+ \\
\end{array}$ \\
\hline & $\begin{array}{l}\text { Robson and Wren } \\
(1999)\end{array}$ & 15 OECD & $\begin{array}{l}\text { - Marginal tax rate } \\
\text { - Average tax rate }\end{array}$ & + \\
\hline & $\begin{array}{l}\text { Bruce and Mohsin } \\
(2006)\end{array}$ & USA & Various tax measures & - \\
\hline & $\begin{array}{l}\text { Stenkula } \\
\text { (forthcoming) }\end{array}$ & Sweden & $\begin{array}{l}\text {-Payroll taxes } \\
\text {-Labor income tax } \\
\text {-Capital gains tax }\end{array}$ & $\begin{array}{l}- \\
0 \\
0\end{array}$ \\
\hline
\end{tabular}


Table 2. Summary statistics for selected variables

\begin{tabular}{|c|c|c|c|c|c|}
\hline & Obs & Mean & Std. Dev. & Min & $\max$ \\
\hline Income (log) & 135 & 30552.37 & 6911.31 & 13583.17 & 49070.01 \\
\hline GEM-nascent & 113 & 3.48 & 1.48 & 1.7 & 8.5 \\
\hline $\begin{array}{l}\text { Net personal average tax at } \\
67 \% \text { of average earnings }\end{array}$ & 135 & 25.31 & 7.08 & 11.5 & 40.9 \\
\hline $\begin{array}{l}\text { Net personal average tax at } \\
100 \% \text { of average earnings }\end{array}$ & 135 & 29.85 & 7.04 & 16.5 & 44.2 \\
\hline $\begin{array}{l}\text { Net personal average tax at } \\
167 \% \text { of average earnings }\end{array}$ & 135 & 36.53 & 7.37 & 21.5 & 51.5 \\
\hline $\begin{array}{l}\text { Net personal marginal tax at } \\
67 \% \text { of average earnings }\end{array}$ & 135 & 36.4 & 9.2 & 15.9 & 61.4 \\
\hline $\begin{array}{l}\text { Net personal marginal tax at } \\
100 \% \text { of average earnings }\end{array}$ & 135 & 43.41 & 9.99 & 20.1 & 69.5 \\
\hline $\begin{array}{l}\text { Net personal marginal tax at } \\
167 \% \text { of average earnings }\end{array}$ & 135 & 47.80 & 8.39 & 28.0 & 63.3 \\
\hline $\begin{array}{l}\text { Tax wedge at } 67 \% \text { of average } \\
\text { earnings }\end{array}$ & 135 & 38.02 & 8.08 & 19.76 & 51.37 \\
\hline $\begin{array}{l}\text { Tax wedge at } 100 \% \text { of } \\
\text { average earnings }\end{array}$ & 135 & 41.84 & 7.96 & 26.16 & 56.66 \\
\hline $\begin{array}{l}\text { Tax wedge at } 167 \% \text { of } \\
\text { average earnings }\end{array}$ & 135 & 47.36 & 7.62 & 31.92 & 62.59 \\
\hline
\end{tabular}


Table 3

A-B GMM estimates

Dependent variable: GEM-nascent

\begin{tabular}{|c|c|c|}
\hline & Tax & iable \\
\hline & $\begin{array}{l}\text { Net personal average } \\
\text { tax rate (at } 100 \% \text { of } \\
\text { average earnings) }\end{array}$ & $\begin{array}{l}\text { Net personal marginal } \\
\text { tax rate (at } 100 \% \text { of } \\
\text { average earnings) }\end{array}$ \\
\hline Endogenous variables & & \\
\hline income $(\log )$ & $\begin{array}{l}4.258 \\
(4.00)\end{array}$ & $\begin{array}{c}3.39 \\
(4.03)\end{array}$ \\
\hline tax rate & $0.169^{*}$ & -0.003 \\
\hline & $(0.09)$ & $(0.02)$ \\
\hline start-up cost & $-0.102 * * *$ & $-0.089 * *$ \\
\hline Exogenous variables & $(0.03)$ & $(0.03)$ \\
\hline credit to private sector & $\begin{array}{l}-0.001 \\
(0.001)\end{array}$ & $\begin{array}{c}-0.002 \\
(0.001)\end{array}$ \\
\hline credit information & $\begin{array}{c}0.186^{* *} \\
(0.08)\end{array}$ & $\begin{array}{c}0.242 * * * \\
(0.08)\end{array}$ \\
\hline unemployment & -0.016 & -0.016 \\
\hline risk & -0.031 & $\begin{array}{l}(0.02) \\
-0.144\end{array}$ \\
\hline & $(0.16)$ & $(0.14)$ \\
\hline secondary education & $\begin{array}{l}-0.001 \\
(0.006)\end{array}$ & $\begin{array}{c}0.003 \\
(0.006)\end{array}$ \\
\hline tertiary education & $\begin{array}{c}0.021 * * * \\
(0.005)\end{array}$ & $\begin{array}{c}0.018 * * * \\
(0.005)\end{array}$ \\
\hline $\begin{array}{l}\text { Obs } \\
\text { Sargan test [P-value] }\end{array}$ & $\begin{array}{c}64 \\
57.48[0.99]\end{array}$ & $\begin{array}{c}64 \\
59.28[0.98]\end{array}$ \\
\hline
\end{tabular}

$*^{*},{ }^{*}$ and ${ }^{* * *}$ represent significance at the 10-percent, 5-percent and 1-percent levels, respectively.

Equations are estimated with a lagged dependent variable and a constant (not shown).

Standard errors are in parentheses.

The AR (2) test results (not shown but may be obtained from the authors) indicates that we can reject the hypothesis that there is second-autocorrelation at the $5 \%$ level of significance.

Note: using at $67 \%$ or $167 \%$ of average earnings does not change the of statistical significance or magnitude of the results 
Table 4

A-B GMM estimates

Dependent variable: GEM-nascent

\begin{tabular}{|c|c|c|c|c|}
\hline & \multicolumn{4}{|c|}{ Tax variables } \\
\hline & (1) & (2) & (3) & (4) \\
\hline & $\begin{array}{l}\text { Net personal } \\
\text { marginal tax rate (at } \\
100 \% \text { of average } \\
\text { earnings) and } \\
\text { progressivity_ } 1^{\text {a }}\end{array}$ & $\begin{array}{l}\text { Net personal } \\
\text { marginal tax rate (at } \\
167 \% \text { of average } \\
\text { earnings) and } \\
\text { progressivity } 2^{b}\end{array}$ & $\begin{array}{l}\text { Average income } \\
\text { tax rate (at } 100 \% \\
\text { of average } \\
\text { earnings) and } \\
\text { progressivity } 1^{c}\end{array}$ & $\begin{array}{l}\text { Average income } \\
\text { tax rate (at } 167 \% \\
\text { of average } \\
\text { earnings) and } \\
\text { progressivity_2 }\end{array}$ \\
\hline \multirow{2}{*}{$\begin{array}{l}\text { Endogenous variables } \\
\text { income }(\log )\end{array}$} & & & & \\
\hline & $\begin{array}{c}3.16 \\
(4.07)\end{array}$ & $\begin{array}{c}2.60 \\
(4.10)\end{array}$ & $\begin{array}{c}0.79 \\
(4.20)\end{array}$ & $\begin{array}{c}0.78 \\
(4.27)\end{array}$ \\
\hline \multirow[t]{2}{*}{ tax rate } & -0.057 & -0.050 & 0.027 & 0.112 \\
\hline & $(0.048)$ & $(0.049)$ & $(0.09)$ & $(0.08)$ \\
\hline tax progressivity & $\begin{array}{c}-0.055^{* *} \\
(0.02)\end{array}$ & $\begin{array}{c}-0.055^{* *} \\
(0.02)\end{array}$ & $\begin{array}{c}0.19 \\
(0.11)\end{array}$ & $\begin{array}{c}-0.348^{* *} \\
(0.14)\end{array}$ \\
\hline start-up cost & $\begin{array}{c}-0.093 * * \\
(0.03)\end{array}$ & $\begin{array}{c}-0.092 * * \\
(0.03)\end{array}$ & $\begin{array}{c}-0.086^{* *} \\
(0.03)\end{array}$ & $\begin{array}{c}-0.122 * * * \\
(0.03)\end{array}$ \\
\hline \multirow{2}{*}{$\begin{array}{l}\text { Exogenous variables } \\
\text { credit to private sector }\end{array}$} & & & & \\
\hline & $\begin{array}{c}-0.002 * \\
(0.001)\end{array}$ & $\begin{array}{c}-0.002 \\
(0.001)\end{array}$ & $\begin{array}{r}-0.0015 \\
(0.001)\end{array}$ & $\begin{array}{r}-0.0007 \\
(0.001)\end{array}$ \\
\hline credit information & $\begin{array}{c}0.271 * * * \\
(0.08)\end{array}$ & $\begin{array}{c}0.218^{* *} \\
(0.08)\end{array}$ & $\begin{array}{c}0.214^{* *} \\
(0.08)\end{array}$ & $\begin{array}{l}0.147^{*} \\
(0.08)\end{array}$ \\
\hline \multirow[t]{2}{*}{ unemployment } & -0.021 & -0.006 & -0.006 & -0.0009 \\
\hline & $(0.02)$ & $(0.02)$ & $(0.02)$ & $(0.02)$ \\
\hline \multirow[t]{2}{*}{ risk } & -0.161 & -0.115 & -0.147 & 0.089 \\
\hline & $(0.15)$ & $(0.15)$ & $(0.15)$ & $(0.17)$ \\
\hline \multirow[t]{2}{*}{ secondary education } & 0.004 & 0.002 & -0.002 & -0.005 \\
\hline & $(0.006)$ & $(0.006)$ & $(0.007)$ & $(0.007)$ \\
\hline tertiary education & $\begin{array}{c}0.019 * * * \\
(0.005)\end{array}$ & $\begin{array}{c}0.018 * * * \\
(0.005)\end{array}$ & $\begin{array}{c}0.020 * * * \\
(0.005)\end{array}$ & $\begin{array}{c}0.023 * * * \\
(0.005)\end{array}$ \\
\hline Obs & $\frac{(0.005)}{64}$ & $\frac{(0.00 J)}{64}$ & $\frac{(0.00 J)}{64}$ & 64 \\
\hline Sargan test [P-value] & 56.82 [0.99] & $58.27[0.99]$ & 55.98 [0.99] & 53.48 [0.99] \\
\hline
\end{tabular}

$*, * *$ and $* * *$ represent significance at the 10-percent, 5-percent and 1-percent levels, respectively.

a progressivity_1 represents the difference between net personal marginal tax at $100 \%$ and net personal marginal tax rate at $67 \%$ of average earnings.

${ }^{\mathrm{b}}$ progressivity_2 represents the difference between net personal marginal tax at $167 \%$ and net personal marginal tax rate at $100 \%$ of average earnings.

${ }^{c}$ progressivity_1 represents the difference between net personal average tax at $100 \%$ and net personal average tax rate at $67 \%$ of average earnings.

${ }^{\mathrm{d}}$ progressivity_2 represents the difference between net personal average tax at $167 \%$ and net personal average tax rate at $100 \%$ of average earnings

Equations are estimated with a lagged dependent variable and a constant (not shown).

Standard errors are in parentheses. The AR (2) test results (not shown but may be obtained from the authors) indicates that we can reject the hypothesis that there is second-autocorrelation at the $5 \%$ level of significance. 
Table 5

GMM estimates - Robustness checks

Tax variables: Net personal average income tax rates (at 100\% and $167 \%$ of average earnings), and progressivity_1 (difference between net personal average tax at $100 \%$ and net personal average tax rate at $67 \%$ of average earnings) and progressivity_2 (difference between net personal average tax at $167 \%$ and net personal average tax rate at $100 \%$ of average earnings)

Dependent variable: GEM-nascent

\begin{tabular}{|c|c|c|c|c|}
\hline & $(1)$ & $(2)$ & (3) & (4) \\
\hline \multirow{3}{*}{$\begin{array}{l}\text { Endogenous variables } \\
\text { income }(\log )\end{array}$} & & & & \\
\hline & $8.14 *$ & 7.56 & -0.836 & 0.217 \\
\hline & $(4.29)$ & $(5.16)$ & $(4.43)$ & $(4.83)$ \\
\hline net personal average tax rate at & 0.207 & & 0.083 & \\
\hline $100 \%$ of average earnings & $(0.13)$ & & $(0.104)$ & \\
\hline progressivity_1 & $\begin{array}{r}0.138 \\
(0.11)\end{array}$ & & $\begin{array}{c}0.234 * * \\
(0.10)\end{array}$ & \\
\hline net personal average tax rate at & & $0.236^{* *}$ & & 0.137 \\
\hline $167 \%$ of average earnings & & $(0.118)$ & & $(0.10)$ \\
\hline progressivity_2 & & $\begin{array}{l}-0.436 * * * \\
(0.16)\end{array}$ & & $\begin{array}{c}-0.346^{* *} \\
(0.14)\end{array}$ \\
\hline start-up cost & $\begin{array}{l}-0.155^{* * *} \\
(043)\end{array}$ & $-0.179 * * *$ & $-0.135 * * *$ & $-0.154 * * *$ \\
\hline subsidies & $\begin{array}{c}-0.084^{* * * *} \\
(0.029)\end{array}$ & $\begin{array}{c}-0.085^{* * *} \\
(0.030)\end{array}$ & & \\
\hline government expenditure & & & $\begin{array}{c}-0.320 * * * \\
(0.15)\end{array}$ & $\begin{array}{l}-0.265^{*} \\
(0.159)\end{array}$ \\
\hline Exogenous variables & & & & \\
\hline & $\begin{array}{r}0.0004 \\
(0.001)\end{array}$ & $\begin{array}{l}0.0001 \\
(0.002)\end{array}$ & $\begin{array}{c}0.0003 \\
(0.0014)\end{array}$ & $\begin{array}{c}0.0002 \\
(0.0014)\end{array}$ \\
\hline credit information & $\begin{array}{l}0.145 \\
(0.105)\end{array}$ & $\begin{array}{c}0.143 \\
(0.106)\end{array}$ & $\begin{array}{c}0.186^{* *} \\
(0.08)\end{array}$ & $\begin{array}{l}0.149^{*} \\
(0.09)\end{array}$ \\
\hline unemployment & $\begin{array}{c}0.065^{* *} \\
(0.03)\end{array}$ & $\begin{array}{l}0.060^{*} \\
(0.03)\end{array}$ & $\begin{array}{l}0.017 \\
(0.02)\end{array}$ & $\begin{array}{l}0.007 \\
(0.02)\end{array}$ \\
\hline risk & $\begin{array}{c}0.210 \\
(0.224)\end{array}$ & $\begin{array}{l}0.256 \\
(0227)\end{array}$ & $\begin{array}{l}0.036 \\
(0.18)\end{array}$ & $\begin{array}{l}0.162 \\
0.18)\end{array}$ \\
\hline secondary education & $\begin{array}{l}-0.006 \\
(0.008)\end{array}$ & $\begin{array}{l}-0.003 \\
(0.008)\end{array}$ & $\begin{array}{l}-0.007 \\
(0.007)\end{array}$ & $\begin{array}{l}-0.004 \\
(0.007)\end{array}$ \\
\hline tertiary education & $0.020 * * *$ & $0.020 * * *$ & $0.022 * * *$ & $0.023 * * *$ \\
\hline & $(0.005)$ & $(0.006)$ & $(0.005)$ & $(0.005)$ \\
\hline inflation $^{\mathrm{a}}$ & $\begin{array}{c}0.098 * * * \\
(0.03)\end{array}$ & $\begin{array}{l}0.074 * \\
(0.04)\end{array}$ & $\begin{array}{l}0.021 \\
(0.03)\end{array}$ & $\begin{array}{r}-0.002 \\
(0.03)\end{array}$ \\
\hline Obs & 64 & 64 & 64 & 64 \\
\hline Sargan test ${ }^{\mathrm{a}}$ [P-value] & $\begin{array}{l}40.25 \\
\lceil 0.99]\end{array}$ & $\begin{array}{l}39.29 \\
{[0.99]}\end{array}$ & $\begin{array}{l}52.59 \\
{[0.99]}\end{array}$ & $\begin{array}{l}51.52 \\
{[0.99]}\end{array}$ \\
\hline
\end{tabular}

$*, * *$ and ${ }^{* * *}$ represent significance at the 10-percent, 5-percent and 1-percent levels, respectively. Equations are estimated with a lagged dependent variable and a constant (not shown).

Standard errors are in parentheses.

The AR (2) test results (not shown but may be obtained from the authors) indicates that we can reject the hypothesis that there is second-autocorrelation at the $5 \%$ level of significance. 
Table 6

GMM estimates

Tax variables: Tax wedges (at $100 \%$ and $167 \%$ of average earnings) and

progressivity_1 (difference between tax wedge at $100 \%$ and tax wedge at $67 \%$ of average earnings)and progressivity_2 (difference between tax wedge at $167 \%$ and tax wedge at $100 \%$ of average earnings)

Dependent variable: GEM-nascent

\begin{tabular}{|c|c|c|c|c|c|c|}
\hline & (1) & (2) & (3) & (4) & $(5)$ & (6) \\
\hline \multirow{2}{*}{$\begin{array}{l}\text { Endogenous variables } \\
\text { income }(\log )\end{array}$} & & & & & & \\
\hline & $\begin{array}{c}0.89 \\
(4.17)\end{array}$ & $\begin{array}{c}0.92 \\
(4.10)\end{array}$ & $\begin{array}{c}6.68 \\
(466)\end{array}$ & $\begin{array}{c}6.24 \\
(484)\end{array}$ & $\begin{array}{l}-1.37 \\
(437)\end{array}$ & -0.065 \\
\hline tax wedge at $100 \%$ of & 0.075 & & 0.179 & & 0.062 & \\
\hline average earnings & $(0.12)$ & & $(0.136)$ & & $(0.12)$ & \\
\hline \multirow{4}{*}{$\begin{array}{l}\text { progressivity_1 } \\
\text { tax wedge at } 167 \% \text { of } \\
\text { average earnings } \\
\text { Progressivity } 2\end{array}$} & $\begin{array}{c}0.143^{* *} \\
(0.06)\end{array}$ & & $\begin{array}{c}0.147 * * \\
(0.07)\end{array}$ & & $\begin{array}{c}0.184 * * * \\
(0.06)\end{array}$ & \\
\hline & & 0.142 & & $0.240^{*}$ & & 0.144 \\
\hline & & $(0.11)$ & & $(0.12)$ & & $(0.12)$ \\
\hline & & $\begin{array}{c}-0.455^{* * *} \\
(0.15)\end{array}$ & & $\begin{array}{c}-0.493 * * * \\
(0.16)\end{array}$ & & $\begin{array}{c}-0.426^{* * *} \\
(0.15)\end{array}$ \\
\hline & $-0.079 * *$ & $-0.130 * *$ & $-0.139 * * *$ & $-0.175^{* *}$ & $-0.117 * * *$ & $-0.150^{* * *}$ \\
\hline Subsidies & & & $\begin{array}{c}-0.084 * * * \\
(0.029)\end{array}$ & $\begin{array}{c}(0.042) \\
-0.076^{* *} * \\
(0.029)\end{array}$ & & \\
\hline \multirow{2}{*}{$\begin{array}{l}\text { government } \\
\text { expenditure } \\
\text { Exogenous variables } \\
\text { credit to private sector }\end{array}$} & & & & & $\begin{array}{c}-0.318 * * \\
(0.015)\end{array}$ & $\begin{array}{l}-0.205 \\
(0.157)\end{array}$ \\
\hline & $\begin{array}{l}-0.0012 \\
(0.0013)\end{array}$ & $\begin{array}{c}-0.0007 \\
(0.0013)\end{array}$ & $\begin{array}{l}-0.0007 \\
(0.0016)\end{array}$ & $\begin{array}{c}-0.0002 \\
(0.0017)\end{array}$ & $\begin{array}{l}0.0003 \\
(0.001)\end{array}$ & $\begin{array}{c}0.0003 \\
(0.0016)\end{array}$ \\
\hline credit information & $0.186^{* *}$ & $\begin{array}{c}0.137 \\
(0.088)\end{array}$ & $\begin{array}{c}0.114 \\
(0.109)\end{array}$ & $\begin{array}{c}0.134 \\
(0.109)\end{array}$ & $0.171 *$ & 0.146 \\
\hline \multirow[t]{2}{*}{ unemployment } & -0.0003 & -0.005 & $0.078^{* *}$ & 0.052 & 0.027 & 0.004 \\
\hline & $(0.02)$ & $(0.02)$ & $(0.03)$ & $(0.03)$ & $(0.024)$ & $(0.02$ \\
\hline \multirow[t]{2}{*}{ Risk } & -0.128 & -0.120 & 0.204 & 0.242 & 0.007 & 0.151 \\
\hline & $(0.16)$ & $(0.17)$ & $(0.22)$ & $(0.23)$ & $(0.18)$ & $(0.18$ \\
\hline \multirow[t]{2}{*}{ secondary education } & -0.004 & -0.006 & -0.009 & -0.005 & -0.008 & -0.006 \\
\hline & $(0.007)$ & $(0.007)$ & $(0.009)$ & $(0.008)$ & $(0.007)$ & $(0.007$ \\
\hline \multirow[t]{2}{*}{ tertiary education } & $0.021 * * *$ & $0.024 * * *$ & $0.021 * * *$ & $0.021 * * *$ & $0.022 * * *$ & $0.024 * * *$ \\
\hline & $(0.005)$ & $(0.005)$ & $(0.006)$ & $(0.006)$ & $(0.005)$ & $(0.005$ \\
\hline \multirow[t]{2}{*}{ inflation $^{\mathrm{a}}$} & & & $0.103 * * *$ & 0.064 & 0.023 & -0.003 \\
\hline & & & $(0.03)$ & $(0.04)$ & $(0.03)$ & $(0.04)$ \\
\hline Obs & 64 & 64 & 64 & 64 & 64 & 64 \\
\hline \multirow[t]{2}{*}{ Sargan test ${ }^{\mathrm{a}}[\mathrm{P}$-value $]$} & 54.13 & 53.71 & 38.92 & 40.77 & 50.13 & 51.62 \\
\hline & [0.99] & [0.99] & [0.99] & [0.99] & [0.99] & [0.99] \\
\hline
\end{tabular}

$*, * *$ and ${ }^{* * *}$ represent significance at the 10-percent, 5-percent and 1-percent levels, respectively.

Equations are estimated with a lagged dependent variable and a constant (not shown).

Standard errors are in parentheses.

The AR (2) test results (not shown but may be obtained from the authors) indicates that we can reject

the hypothesis that there is second-autocorrelation at the 5\% level of significance. 


\section{Appendix A}

Table A1

Pooled-data estimates

Dependent variable: GEM-nascent

\begin{tabular}{|c|c|c|c|c|}
\hline & \multicolumn{4}{|c|}{ Tax variables } \\
\hline & $\begin{array}{c}\text { Net personal } \\
\text { average tax at } \\
100 \% \text { of } \\
\text { average } \\
\text { earnings } \\
\end{array}$ & $\begin{array}{l}\text { Net personal } \\
\text { marginal tax } \\
\text { at } 100 \% \text { of } \\
\text { average } \\
\text { earnings } \\
\end{array}$ & $\begin{array}{c}\text { net personal } \\
\text { marginal tax rate at } \\
100 \% \text { of average } \\
\text { earnings and } \\
\text { progressivity_1 }\end{array}$ & $\begin{array}{c}\text { net personal } \\
\text { marginal tax rate at } \\
167 \% \text { of average } \\
\text { earnings and } \\
\text { progressivity_2 }\end{array}$ \\
\hline $\operatorname{tax}$ & $\begin{array}{c}-0.072 * * * \\
(0.021)\end{array}$ & $\begin{array}{c}-0.041^{* *} \\
(0.015) \\
\end{array}$ & $\begin{array}{c}-0.064 * * * \\
(0.015) \\
\end{array}$ & $\begin{array}{c}-0.091 * * * \\
(0.016) \\
\end{array}$ \\
\hline Progressivity_1 & & & $\begin{array}{c}0.049 * * * \\
(0.016)\end{array}$ & \\
\hline Progressivity_2 & & & & $\begin{array}{c}-0.011 \\
(0.020)\end{array}$ \\
\hline start-up cost & $\begin{array}{c}-0.120 * * * \\
(0.02)\end{array}$ & $\begin{array}{c}-0.055^{* *} \\
(0.02) \\
\end{array}$ & $\begin{array}{c}-0.064 * * * \\
(0.02)\end{array}$ & $\begin{array}{c}-0.060 * * * \\
(0.02)\end{array}$ \\
\hline income $(\log )$ & $\begin{array}{l}-1.11 \\
(0.68) \\
\end{array}$ & $\begin{array}{l}-0.84 \\
(0.94) \\
\end{array}$ & $\begin{array}{l}-0.83 \\
(0.87) \\
\end{array}$ & $\begin{array}{r}-1.155 \\
(0.84) \\
\end{array}$ \\
\hline tertiary education & $\begin{array}{c}-0.021 * \\
(0.012)\end{array}$ & $\begin{array}{l}-0.010 \\
(0.012) \\
\end{array}$ & $\begin{array}{l}-0.017 \\
(0.013)\end{array}$ & $\begin{array}{c}0.004 \\
(0.011) \\
\end{array}$ \\
\hline secondary education & $\begin{array}{c}0.042 * * \\
(0.019)\end{array}$ & $\begin{array}{l}0.035^{*} \\
(0.021)\end{array}$ & $\begin{array}{c}0.055^{* *} \\
(0.023) \\
\end{array}$ & $\begin{array}{c}0.042 * * \\
(0.018)\end{array}$ \\
\hline risk & $\begin{array}{c}-2.31 * * * \\
(0.32)\end{array}$ & $\begin{array}{c}-2.31 * * * \\
(0.35)\end{array}$ & $\begin{array}{c}-2.39 * * * \\
(0.4)\end{array}$ & $\begin{array}{c}-1.94 * * * \\
(0.31)\end{array}$ \\
\hline unemployment & $\begin{array}{c}-0.206^{* * *} \\
(0.07)\end{array}$ & $\begin{array}{l}-0.072 \\
(0.07)\end{array}$ & $\begin{array}{l}-0.067 \\
(0.07)\end{array}$ & $\begin{array}{c}-0.132 * * \\
(0.06)\end{array}$ \\
\hline credit information & $\begin{array}{c}0.584 * * * \\
(0.17)\end{array}$ & $\begin{array}{c}0.667 * * * \\
(0.19)\end{array}$ & $\begin{array}{c}0.759^{* * *} \\
(0.20)\end{array}$ & $\begin{array}{c}0.33 \\
(0.20)\end{array}$ \\
\hline credit to private sector & $\begin{array}{c}-0.006^{*} \\
(0.004)\end{array}$ & $\begin{array}{l}-0.002 \\
(0.004)\end{array}$ & $\begin{array}{l}-0.005 \\
(0.004)\end{array}$ & $\begin{array}{l}-0.003 \\
(0.004)\end{array}$ \\
\hline No. of obs. & 79 & 79 & 79 & 79 \\
\hline Fstat & 11.65 & 5.75 & 5.92 & 9.37 \\
\hline
\end{tabular}

Robust standard errors are in parentheses.

$*$ indicates significance at $0.10 * *$ indicates significance at 0.05 and $* * *$ indicates significance at 0.01 .

${ }^{a}$ progressivity_1 represents the difference between net personal marginal tax at $100 \%$ and net personal marginal tax rate at $67 \%$ of average earnings.

${ }^{\mathrm{b}}$ progressivity_2 represents the difference between net personal marginal tax at $167 \%$ and net personal marginal tax rate at $100 \%$ of average earnings. 


\section{Appendix B}

\section{$\underline{\text { Variables and data sources }}$}

Data on all tax rates from the OECD database online. Tax wedges (on labour) is the difference between what employers pay out in wages and social security charges and what employees take home after tax and social security deductions plus any cash benefits for which they may be eligible, can be a disincentive to work (for a more detailed description see www.OEDC.org)

Risk: This variable is proxied by the International Country Risk Guide (ICRG) 'investment profile' component, measured on a scale of 0 to 12. It is an assessment of factors affecting the risk to investment that are not covered by other political, economic and financial risk components. The risk rating assigned is the sum of three subcomponents, each with a maximum score of four points and a minimum score of 0 points. A score of 4 points equates to very low risk and a score of 0 points implies very high risk.

Self-employed, total (\% of total employed): Self employed workers are those workers who, working on their own account or with one or a few partners or in cooperative, hold the type of jobs defined as a "self-employment jobs. Source: LABORSTA dataset, International Labor Organization.

The source of the following variables and their description is Global Entrepreneurship Monitor (GEM) database online.

GEM- Nascent: Nascent Entrepreneurship Rate is the percentage of 18-64 population who are currently a nascent entrepreneur, i.e., actively involved in setting up a business they will own or co-own; this business has not paid salaries, wages, or any other payments to the owners for more than three months.

The source of the following variables and their description is World Bank Development Indicators \& Global Development Finance database online.

Cost of business start-up procedures (\% of GNI per capita) Cost to register a business is normalized by presenting it as a percentage of gross national income (GNI) per capita. 
Domestic credit to private sector (\% of GDP) Domestic credit to private sector refers to financial resources provided to the private sector, such as through loans, purchases of nonequity securities, and trade credits and other accounts receivable, that establish a claim for repayment. For some countries these claims include credit to public enterprises.

GDP per capita, PPP (constant 2005 international \$) GDP per capita based on purchasing power parity (PPP). PPP GDP is gross domestic product converted to international dollars using purchasing power parity rates. An international dollar has the same purchasing power over GDP as the U.S. dollar has in the United States. GDP at purchaser's prices is the sum of gross value added by all resident producers in the economy plus any product taxes and minus any subsidies not included in the value of the products. It is calculated without making deductions for depreciation of fabricated assets or for depletion and degradation of natural resources. Data are in constant 2005 international dollars.

General government final consumption expenditure ( $\%$ of GDP). General government final consumption expenditure (formerly general government consumption) includes all government current expenditures for purchases of goods and services (including compensation of employees). It also includes most expenditures on national defense and security, but excludes government military expenditures that are part of government capital formation.

Subsidies and other transfers (\% of expense). Subsidies, grants, and other social benefits include all unrequited, nonrepayable transfers on current account to private and public enterprises; grants to foreign governments, international organizations, and other government units; and social security, social assistance benefits, and employer social benefits in cash and in kind.

Unemployment, total (\% of total labor force) Unemployment refers to the share of the labor force that is without work but available for and seeking employment. Definitions of labor force and unemployment differ by country.

School enrollment, tertiary (\% gross) Gross enrollment ratio is the ratio of total enrollment, regardless of age, to the population of the age group that officially corresponds to the level of education shown. Tertiary education, whether or not to an advanced research qualification, normally requires, as a minimum condition of admission, the successful completion of education at the secondary level. 
School enrollment, secondary (\% gross) Gross enrollment ratio is the ratio of total enrollment, regardless of age, to the population of the age group that officially corresponds to the level of education shown. Secondary education completes the provision of basic education that began at the primary level, and aims at laying the foundations for lifelong learning and human development, by offering more subject- or skill-oriented instruction using more specialized teachers.

Inflation: Inflation as measured by the annual growth rate of the GDP implicit deflator shows the rate of price change in the economy as a whole. The GDP implicit deflator is the ratio of GDP in current local currency to GDP in constant local currency. 